\title{
To immerse or not? Experimenting with two virtual retail environments
}

Virtual retail environments

Savvas Papagiannidis

Newcastle University Business School, Newcastle upon Tyne, UK

Eleonora Pantano

The Business School, Middlesex University, London, UK

Eric W.K. See-To

Department of Industrial and Systems Engineering,

Hong Kong Polytechnic University, Kowloon, Hong Kong

Charles Dennis

The Business School, Middlesex University, London, UK, and

Michael Bourlakis

Cranfield School of Management, Cranfield University, Cranfield, UK

\begin{abstract}
Purpose - The purpose of this paper is to examine the determinants of users' simulated experience in a virtual store and to show the subsequent impact of that experience on engagement. The outcome of that engagement is examined in relation to enjoyment, satisfaction and purchase intentions.

Design/methodology/approach - The method comprised an experiment comparing users' perceptions of a standard 2D online clothing store with an enhanced, immersive one that aimed to provide shopping value approaching that of a traditional store by using a 3D experience where participants wore special glasses and a data glove.

Findings - Results demonstrate the major role of telepresence components in simulated experience and the critical role of that experience, along with hedonic and utilitarian values, in engagement. Purchase intention is influenced by satisfaction, which is in turn influenced by enjoyment and engagement. Engagement in turn is influenced by utilitarian and hedonic value and the experience of product simulation or telepresence, which is composed of control, colour and graphics vividness, and 3D authenticity. In the immersive, 3D environment, experience is more associated with engagement and enjoyment, leading to greater purchase intention. The immersive, 3D environment, thus, has the potential to rival traditional shopping in terms of experience, resulting in higher sales for retailers and satisfaction for consumers.

Originality/value - This work has evaluated a robust model of purchase intention and demonstrated it to hold not only in a 3D environment on a conventional computer platform, but also in an immersive one, where participants wear special glasses and a data glove.
\end{abstract}

Keywords Simulation, Online shopping, E-commerce (B2B/B2C/B2G/G2C), Virtual world

Paper type Research paper

(C) Savvas Papagiannidis, Eleonora Pantano, Eric See-To, Charles Dennis, Michael Bourlakis. Published by Emerald Publishing Limited. This article is published under the Creative Commons Attribution (CC BY 4.0) licence. Anyone may reproduce, distribute, translate and create derivative works of this article (for both commercial \& non-commercial purposes), subject to full attribution to the original publication and authors. The full terms of this licence may be seen at http://creativecommons.org/licences/by/4.0/ legalcode

The work described in this paper was partially supported by a grant from the Department of Industrial and Systems Engineering, Hong Kong Polytechnic University, Hong Kong, China (Project No. G-YBE4). 


\section{Introduction}

Traditional store retailers have long used retail "atmosphere" or environment stimulus cues, such as colour, music and aroma, to influence consumers' shopping behaviour (Mehrabian and Russell, 1974). In recent years, several disruptive patterns have dramatically changed the retail industry, while pushing traditional retailing to evolve in terms of structure (Pantano, 2014). e-Retailers are using atmospherics to compensate for the lack of a physical environment, including graphics, visuals, audio, colour, video (Dennis et al., 2009; Eroglu et al., 2003) and, centrally to this study, three-dimensional (3D) virtual reality, which we term the "immersive retail environment" (Laria and Pantano, 2012). In this scenario, Bourlakis et al. (2009) identified metaverse retailing as an evolution of electronic retailing, representing a shift from a product orientation to a consumer experience orientation. User experience in retail settings emerges from the interactions consumers have with a product, environment and retailer, and it has a holistic nature involving cognitive, affective, emotional, social and physical responses to the retail environment (Verhoef et al., 2009). This experience might be influenced by both elements under retailer control (e.g. assortment, price, layout, etc.) and other factors that cannot be managed by retailers (e.g. shopping motivations, etc.). The adoption of technologies might influence these factors and encourage consumers to shop online.

Advances in information technology empower consumers with efficient new tools for evaluating the products online, while providing realistic, engaging online shopping experiences where consumers directly interact with products without direct employee assistance (Blazquez, 2014). Hence, even the e-commerce environment is able to provide new virtual and exciting experiences for consumers with consequences for brick-and-mortar stores. A new challenge arises in this new competitive scenario, which is the need to rethink the in-store shopping experience through the support of technologies, by providing innovative advances in touch-points including the integration of online tools and automatic systems (i.e. self-service and recommendation technologies). Moreover, recent advances in technology also provide new tools for enhancing consumers' shopping experiences by integrating virtual worlds within traditional brick-and-mortar stores. Nonetheless, there is still scope for further research into retailing in virtual worlds (Lee and Domina, 2013) which has so far been primarily concerned with shopping of virtual rather than real-world products (Guo and Barnes, 2011).

In this research, we build upon recently published work by Papagiannidis et al. (2013) that examines a number of ways of modelling the determinants of users' simulated experience in a virtual store and the impact of engagement, enjoyment and satisfaction as well as purchase intentions. We expand this work by adopting the suggested optimum model (Papagiannidis et al., 2013) and extending the context to an immersive 3D retail store environment enabled by virtual reality technology, where participants wear special glasses and a data glove. The impact of technology factors, and the subsequent simulated retail experiences on user engagement and enjoyment are compared and contrasted for the two different resolutions for each of the environments. Given that the locus of customer value is shifting from product and service to experience and interaction (Prahalad and Ramaswamy, 2004), such a comparison is important as it cannot be assumed that access via different technologies to the same virtual space will produce the same result. Overall, we aim to test current theory by cross-analysing and extending the application of a specific model within two virtual retail environments (2D vs 3D desktop environments). Our work fills a gap in the contemporary literature by testing a theoretical, integrative model which takes into account a range of attributes (e.g. hedonic value, utilitarian value, etc.) leading to simulated experience and, in turn, it examines their impact on various outcomes including purchase intention. Hence, our key contribution is the provision of a theoretical path which maps consumer behaviour in relation to various attributes and examines the process leading to purchase intention. By cross-analysing this integrative model/theoretical path within two virtual retail environments (the second - immersive 
3D-being a recent and novel one), we aim to provide new theoretical and practical insights into immersive environments and make a key contribution to this field of study.

The paper continues by presenting the relevant literature review and the model adopted. It will then discuss the methodology followed, especially when it came to using stereoscopic tools for $3 \mathrm{D}$ visualisation. Following this, we present the results of the experiments and discuss the implications for theory and practice.

\section{Literature review}

Although 3D-based retail environments can potentially operate as stand-alone systems, it is only through virtual worlds that they have become more prominent as the latter extended their reach and importance. Social virtual worlds are immersive, persistent, shared, computermediated 3D environments, designed for real-time social interaction (in the context of varying applications such as education or business) and entertainment, where the users are represented by individual avatars (Bartle, 2004; Zhou et al., 2011). These worlds extend our physical universe by adding new dimensions and domains for economic, social and leisure activities (Papagiannidis et al., 2008). Not surprisingly, among these activities shopping, in various forms and shapes depending on the world's theme, features high in user preferences. Virtual commodities can act in essentially the same social roles as material goods, with users consuming virtual goods in order to express themselves and their identities, establish a social status, mark group membership, etc. (Lehdonvirta et al., 2009). Virtual retailing often resembles the traditional approaches, but is not bound by them and can go beyond them. When conduits between the real and the virtual exist, retailers are encouraged to consider such worlds as potential interfaces for their online arms. For instance in Second Life, one of the well-known social virtual worlds, it is possible to exchange real money for Linden dollars and purchase virtual good with them and vice versa. Many real organisations have entered such worlds, which first raised questions about the similarities and differences of the delivery of retailing in virtual worlds, in the bricks-and-mortar world, and on the internet and second whether retailing in virtual worlds would ever scale to become a future 3D platform for electronic commerce (Messinger et al., 2009). A few have even attempted to integrate their offline operations with the virtual world ones (Papagiannidis and Bourlakis, 2010).

Accessing such 3D worlds was achieved through a flat interface, i.e. a computer monitor, which did not offer a 3D perspective and interaction. With technology rapidly advancing one could envisage that it is only a matter of time until virtual worlds can be experienced in a truly 3D manner. This could in turn enhance user engagement and immersion. For example, televisions that support 3D viewing using appropriate glasses can now be found in consumers' living rooms. This transition can significantly alter user behaviour, which has typically been studied in the context of the established virtual worlds (see e.g. Barnes et al., 2015; Domina et al., 2012; Gadalla et al., 2013; Krasonikolakis et al., 2014). Studying the differences between these two approaches is important in appreciating the potential changes technological advances and retail innovations can result in. This has significant implications as novel, exciting and engaging shopping experiences can positively affect consumer buying behaviour (Pantano and Naccarato, 2010). In fact, the retail industry is witnessing constant changes prompted by the continuous progress in information and communication technologies. For instance, augmented reality and haptic technologies, social networks, mobile technologies and multichannel environments highlight the heterogeneity of the innovative systems to be introduced for enhancing the retail process, and in turn, they deliver new stimuli while providing innovative sensorial experiences able to communicate and promote products, services, and firms (Demirkan and Spohrer, 2014; Kaplan, 2012; Kushwaha and Shankar, 2013; Pantano and Viassone, 2015). Hence, these innovations can be viewed as enablers of change that have dramatically modified the retail landscape (Hopping, 2000; Pantano, 2014); they are able to provide new

Virtual retail environments 
entertaining experiences for consumers, while integrating leisure, technologies and retail establishments (Demirkan and Spohrer, 2014; Jones, 1999; Pantano and Viassone, 2015; Poncin and Mimoun, 2014). Consumers show an increasing desire to have a more engaging experience while shopping. This implies that the consumers have high level of expectations towards technology-based innovations able to support them (utilitarian value) while entertaining them (hedonic value). Hassouneh and Brengman (2011) found that users had an overall positive perception when it came to use a virtual world such as Second Life for shopping, concluding that this was not though just attributed to the virtual worlds' characteristics but also to the fictitious possibilities offered by such worlds. Consequently such positive perception may not apply if the user is looking to purchase products for real use.

In the next section, we present our conceptual model for studying user expectations and overall experience and how they affect shopping intentions. We also undertake a comparison between a $2 \mathrm{D}$ and a $3 \mathrm{D}$ retail environment in order to examine the relative importance of space and interactivity.

\section{Conceptual model and hypotheses}

The term "telepresence" was introduced by Minsky (1980), indicating the degree to which a user feels "transported" via a virtual "tele-porting system". More recently, the term telepresence has been used to describe the sense of being "transported" by a new technology. Hence, this construct describes the sense of presence within an interactive environment, and it is often used as an antecedent of user experience (Sukoco and Wu, 2011). Fiore, Kim and Lee (2005) propose three key determinants of telepresence: "the ability to control the relationship of one's senses to the stimulus" (control), "the ability to modify the stimulus" in order increase the realism and excitement of the experience (colour and graphics vividness) and finally "the extent to which online sensory information approximates the real world stimulus" (3D authenticity), which refers to the degree to which the virtual environment may imitate the real one for products and services. Similarly, Sheridan (1992) suggests that virtual model technology will involve all three determinants, while Sukoco and $\mathrm{Wu}$ (2011) based the telepresence concept on control and interactivity. Previous research found evidence that behavioural control (or controllability), in other words users' confidence, is their ability to use a certain technology, serves as the basis for the individual's intention to use a certain system (Hernandez et al., 2009; Kim et al., 2011). Vividness might affect users' emotional states, by providing hedonic pleasure to users, reducing their anxiety in using the technology, perhaps leading to increased time spent online and repeat visits (Shih, 1998; Koufaris, 2002). Finally, there is authenticity. As frequently demonstrated in the tourism industry, virtual reality has the potential to provide virtual experiences that consumers may accept as substitutes for real products (Guttentag, 2010; Dennis and Jayawardhena, 2010). Past studies on consumer behaviour have further emphasised the trade-off between utilitarian value and hedonic value emerging in shopping experience, with the balance potentially influencing the purchase intention (Olsen and Skallerud, 2011; Fiore and Kim, 2007). Utilitarian values characterize consumers who tend to employ cognitive processing for achieving the shopping purpose; thus, these values help consumers to save time, reduce effort while shopping (e.g. when comparing or choosing a certain product) (Fiore, Kim and Lee, 2005; Dennis et al., 2010). On the other hand, hedonic values concern the emotional state emerging from the experience, and may include all elements that cause a state of pleasure, such as colour, graphics, animation and other design elements (Coursaris et al., 2008; Al-Qeisi et al., 2014; Vila and Kuster, 2011). In other words, hedonic values emerge from fun, enjoyment, entertainment and excitement while interacting with the virtual environment, whereas the overall virtual experiences engage consumers and influence their purchasing behaviour (Fiore, Jin and Kim, 2005). In the specific context of this current study, prior research reports the influence of hedonic aspects while consumers interact with products 
in virtual environments developed for apparel shopping (Kim and Forsythe, 2007). Findings reveal that consumers' positive attitudes are elicited by both utilitarian and hedonic value emerging from the use of the technology, emphasising that when consumers use a technology designed to provide hedonic benefits, they tend to have hedonic motivations rather than utilitarian ones. The idea of "engagement" has been reported in several contexts including psychology, computer science and sociology over the last decade. In particular, engagement consists of a psychological state including involvement and effective usage of cognitive capabilities, as well as creativity (Mollen and Wilson, 2010). Engagement can be classified into two different levels: low and high (Vorderer, 1992). For instance, a user interacting with a product in a real environment involves a high level of engagement, while someone just watching the user interacting with the products has a low level of engagement. Verhagen $e$ t al. (2015) have found that cognitive, social integrative and hedonic benefits appear to be significant in their influence on customer engagement intentions when it comes to virtual customer environments.

Although some technology-oriented perspectives consider shopping media simply as cold information systems, rather than as immersive, hedonic environments, the current trend is to develop new technologies that are able to provide immersive and engaging experiences. Consumers may live through these highly interactive, realistic interfaces, which can make such interfaces key elements for influencing consumers in the direction of buying products with strong hedonic attributes (Childers et al., 2001). Of course, hedonic and utilitarian experiences do not necessarily exclude one another; thus, the new retail environment might elicit both types of experience in different ways. The model developed for this paper (Figure 1) proposes that the dimensions of telepresence, such as control, 3D authenticity, colour and graphics vividness positively impact on a user's experience and, in turn, along with utilitarian and hedonic values, positively affect engagement.

Previous studies have investigated to what extent a simulated experience supports the learning process, enriches shopping activity and improves overall experience, consumers' satisfaction and loyalty (Algharabat and Dennis, 2010b; Pantano and Servidio, 2012). A high level of telepresence encourages consumers to believe that they are more informed about a certain product, by eliciting more positive behaviours towards it (Mollen and Wilson, 2010). To achieve this goal, it is important to provide highly interactive virtual environments (Steuer, 1992), by substituting the actual experience of the products with the opportunity to interact with the product virtually. Thus, the virtual route can frequently offer more options than can be provided in the real context. For example, the virtual

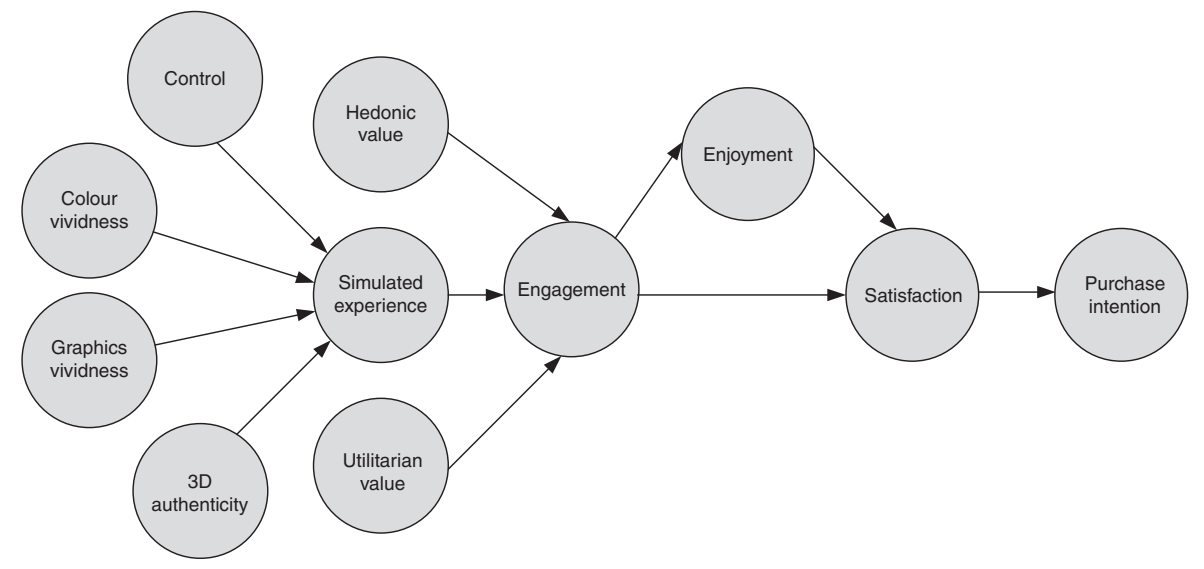

Source: Papagiannidis et al. (2013)
Virtual retail environments

167
Figure 1. Conceptual model 
context can allow users to directly interrogate the product about the manufacturing process or visualise the raw materials, etc. (Fiore, Kim and Lee, 2005). Prior research demonstrates that interactive marketing supports consumer's decision-making processes, improves consumer relationships and facilitates the development of more efficient customised marketing strategies (Yoo et al., 2010). On the other hand, the rich environment and audio-visual stimuli that 3D worlds offer can be a distraction for users when attempting to complete tasks (Nah et al., 2011).

In the current model, simulated experience serves as an intermediate variable between telepresence factors and user engagement. Thus, as technology develops, the performance of telepresence elements such as control and graphics improves. As a consequence, the importance of those elements decreases, despite their important role in the effectiveness of simulation. Recent studies demonstrate greater effects of 3D product visualisation on consumers' attitudes as compared to the effects of traditional 2D internet advertising (Lee, 2012). Current advances in 3D graphics provide new tools for enhancing the realism of virtual experience and make it more similar to the real one. This is achieved by reducing the perceptual distance between the real and the virtual scenarios, developing an efficient match between physical and the digital stores (Laria and Pantano, 2012; Houliez, 2010), by enhancing the sense of being in the environment while interacting with it (Parke, 2005). Amongst other advantages, 3D retail stores add emotional expressiveness (Gadalla et al., 2013) and can enhance social experience (Mäntymäki and Salo, 2011; Verhagen et al., 2012). $3 \mathrm{D}$ virtual experiences allow consumers to view products from different perspectives, angles and distances, as well as explore the different functions and feature of available products (Jiang and Benbasat, 2004) with benefits for positive evaluations of the product. Similarly, the vividness of graphics positively stimulates the user's sensory perceptions through an increased level of interactivity (Cheng et al., 2014), by supporting mental imagery formation (Choi and Taylor, 2014), with benefits for consumers' potential to remember products and gain confidence in the online shopping process (Lee, 2012). Hence, the quality of graphics enhances the realism of the experience and the feeling of interaction within the real environment, while the high level of controllability provides users with a customised and comfortable experience, which may be able to reduce the constraints associated with the lack of physical contact with the product. The quality of the virtual experience, prompted by the quality of visual effects and functionalities (i.e. high level of interactivity), pushes users to a psychological state where they perceive the environment as authentic (Malliet, 2006). Authenticity is a subjective concept, which users may perceive differently accordingly to the context and their personal attitudes towards the technology. Thus, authenticity is linked to user acceptance of the virtual experience (Guttentag, 2010). Accordingly, it is based on a psychological state in which the virtual environment and objects are perceived by users as actual (Algharabat and Dennis, 2011). To achieve this perception, the technology needs to be able to mimic or simulate the experience in the bricks-and-mortar environment, in other words to provide an authentic (virtual) reproduction of the offline experience. Hence, the concept of 3D authenticity relates directly to the users' daily lives, depending on the ability of virtual environment to describe something real (Malliet, 2006). Summarizing these arguments, we propose the following hypotheses:

H1(a-d). Higher levels of (a) control, (b) colour vividness, (c) graphics vividness and (d) $3 \mathrm{D}$ authenticity will be directly associated with increased levels of simulation experience.

H1e. Higher levels of simulation experience will be directly associated with increased engagement with the simulated retail environment.

H1f. Utilitarian experience will be directly associated with increased engagement with the simulated retail environment. 
$H 1 g$. Hedonic experience will be directly associated with increased engagement with the simulated retail environment.

Flow theory suggests that user experience, engagement and enjoyment might be antecedents of satisfaction, with the main goal of modern retail environments is to create superior consumer experiences (Verhoef et al., 2009). Flow is defined as "the state in which people are so intensely involved in an activity that nothing else seems to matter; the experience itself is so enjoyable that people will do it even at great cost, for the sheer sake of doing it" (Csikszentmihalyi, 1990, p. 4). This differs from the concept of telepresence, used in the preliminary stage of our model, as telepresence refers to the feeling of being there (a feeling of immersion within the environment) (Weibel and Wissmath, 2011), whereas flow refers to the feeling of being involved in an action, engagement and enjoyment (Ghani and Deshpande, 1994). Past studies exploited these constructs in several fields (Bakker et al., 2011; Handelsman et al., 2005; Hu and Hui, 2012). Engagement and enjoyment can be produced by the characteristics of the website, such as telepresence and simulated experience. In the context of social virtual worlds, flow has been found to significantly affect intentions to purchase, but telepresence did not do so (Animesh et al., 2011).

In turn, engagement is a driver for enjoyment and consumer satisfaction. Prior studies have empirically highlighted engagement as an antecedent of user satisfaction (Hu and Hui, 2012; Kim et al., 2013). The effectiveness of virtual environments is associated with enjoyment and entertainment, which are in turn positively correlated with user satisfaction (Pantano and Servidio, 2012; Kim and Forsythe, 2007). Also, past research found that social virtual worlds' continuance intentions depended on user satisfaction, which is in turn a function of utilitarian, hedonic and social benefits (Zhou et al., 2012, 2014; Verhagen et al., 2011). Starting from the key role of consumer satisfaction in building and maintaining loyalty (Yoo et al., 2010), end-user satisfaction emerges as the basic element of every user-system interaction, acting as a performance measure of the system (Van Vugt et al., 2009). Much prior research focusses on hedonic and utilitarian shopping values as shopping motivations and the value of shopping experience, yet little attention to date has been paid to the outcomes of shopping value in terms of consumers' behaviour (Jones et al., 2006). To fill this gap, our research provides an integrated framework of analysis of the entire process, mapping consumer behaviour from a new experience in the virtual environment to the final purchase intention. Given the experimental setup of our study, purchase intention refers to the overall intention of participants to buy the products on offer (in our case apparel) after they have experienced the virtual environment. Several studies investigating both online and offline retail settings reveal the strong causal relationship between consumer satisfaction (and experience) and the subsequent purchase intention (e.g. Cronin et al., 2000; Yang and Wu, 2009; Hausman and Siekpe, 2009). The proposed relationships are illustrated schematically in Figure 1. Based on the above, we hypothesise that:

H2. Engagement will be directly associated with increased enjoyment derived from the simulated retail environment.

H3. Enjoyment will be directly associated with increased satisfaction with the simulated retail environment.

H4. Engagement will be directly associated with satisfaction with the simulated retail environment.

H5. Satisfaction with the simulated retail environment will be directly associated with intention to purchase.

It has long been known that shopping is not just about obtaining tangible products but also enjoyment and pleasure (Martineau, 1958), and that an enjoyable shopping experience is 
often reflected in higher shopper satisfaction and spending (e.g. Donovan et al., 1994; Jones, 1999). This is the basis of the "retail theatre" concept, where "[...] the experience revolves around the customer as if he or she were a critical component of a grand theatrical fantasy" (Healy et al., 2007, p. 756). Healy et al. (2007) also note that retail theatre concerns the dynamic element of an experiential environment (as with the immersive 3D environment in our virtual retail store), where a human interacts with aspects of the environment. Therefore, we expect that an immersive 3D environment will create higher levels of engagement, enjoyment and satisfaction, leading to greater purchase intention:

H6. For consumers experiencing an immersive 3D environment, there will be a greater influence of (a) simulated experience on engagement, (b) engagement on enjoyment, (c) enjoyment on satisfaction and (d) satisfaction on purchase intention than for those exposed to the 2D desktop.

\section{Method}

A new virtual retail environment was developed for this study, offering more of a high level of presence prompted by the realistic interface and 3D graphics, enhancing the feeling of immersion in the system. The first phase of the study was to create a 3D virtual desktop application, which has been further compared with an immersive 3D application.

The 3D model of the building containing the store, which was created by an architectural $\mathrm{CAD}$ software programme, with the objects being imported and modified through 3D modelling software in order to develop the basic features for the 3D real-time simulation and the effective store. The 3D modelling software made it possible to identify and set the basic objects' material and related features, which were better defined in the subsequent step through the simulation software for the recognition of the optical characteristics of the objects, such as shadows, reflections, $\alpha$ blending for transparency or bump mapping. Therefore, a more realistic environment was developed through the render-mapping technique, which consisted of the generation of ray-traced images used as textures. Afterwards, the illumination was defined, thus, it was possible to set up the rendering engine parameters and apply the render-map property to the objects. In this way, the ray-tracing engine created the images on which all the optical effects were mapped. The images have a 4,096 ×4,096 pixels resolution in PNG format and contain each single face shading property of the object. In addition to the shadows, most of ray-traced effects were pre-computed, such as ambient occlusion and global illumination. These images were applied to the 3D objects within the real-time environment in order to achieve a good final rendering. The environment could be accessed and browsed through a joystick.

To show the effect of immersion on consumer behaviour, we also created an immersive environment that would overcome the traditional boundaries of desktop applications (such as the limited input devices, the unrealistic interaction through joysticks, etc.). The immersive store was modelled starting from a basic planimetric map of the virtual store including two floors (Plate 1). Objects were created on the basis of standard primitives, and then refined through additional tools. This procedure makes it possible to achieve a better outcome, in terms of the limited number of required polygons while keeping the maximum control of the 3D object topology. The added emphasis on the characteristics of objects in terms of materials and surfaces improves the realism of the final models, with emphasis on lighting and colour. The visual effects of such objects were further defined including transparency, reflections or bump mapping for the multi textured layered materials. The store featured transparent stairs, a lift (with transparent walls and door), and a few booths laid out as partitions, shelves and corridors that users can explore, as in a physical store. The final outcome is a realistic model loaded into the stereoscopic system. Quest3D software allows the effective development of the real-time application, as well as the programming of the whole virtual environment through a building-blocks paradigm. 
(a)

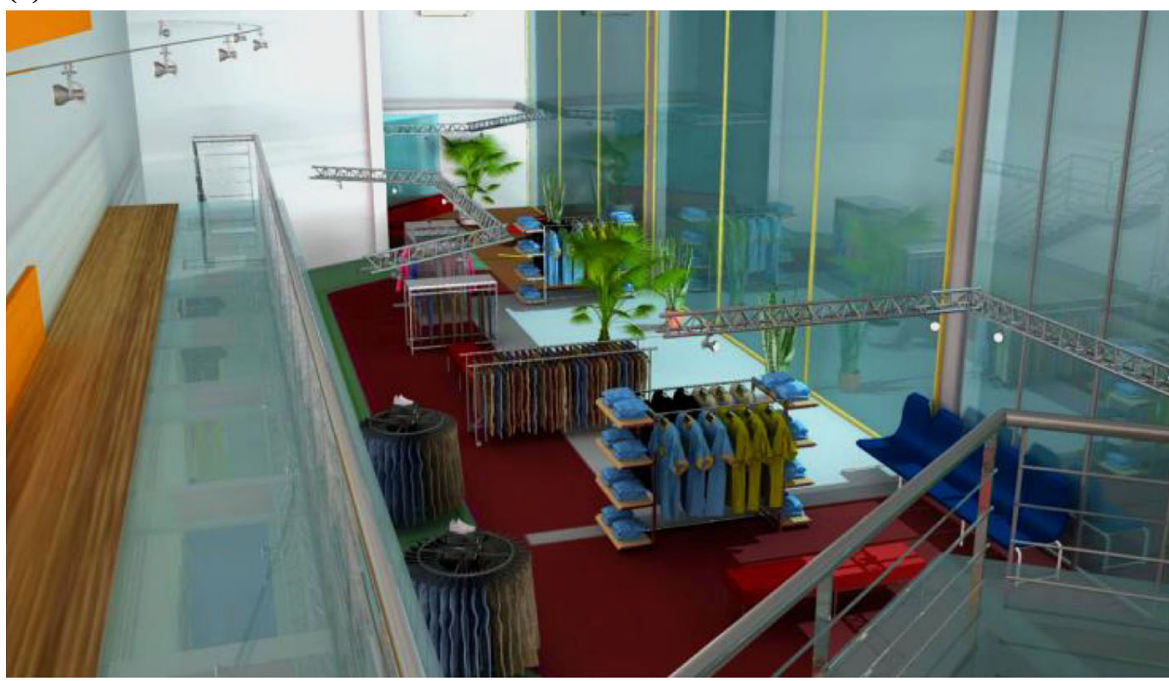

(b)

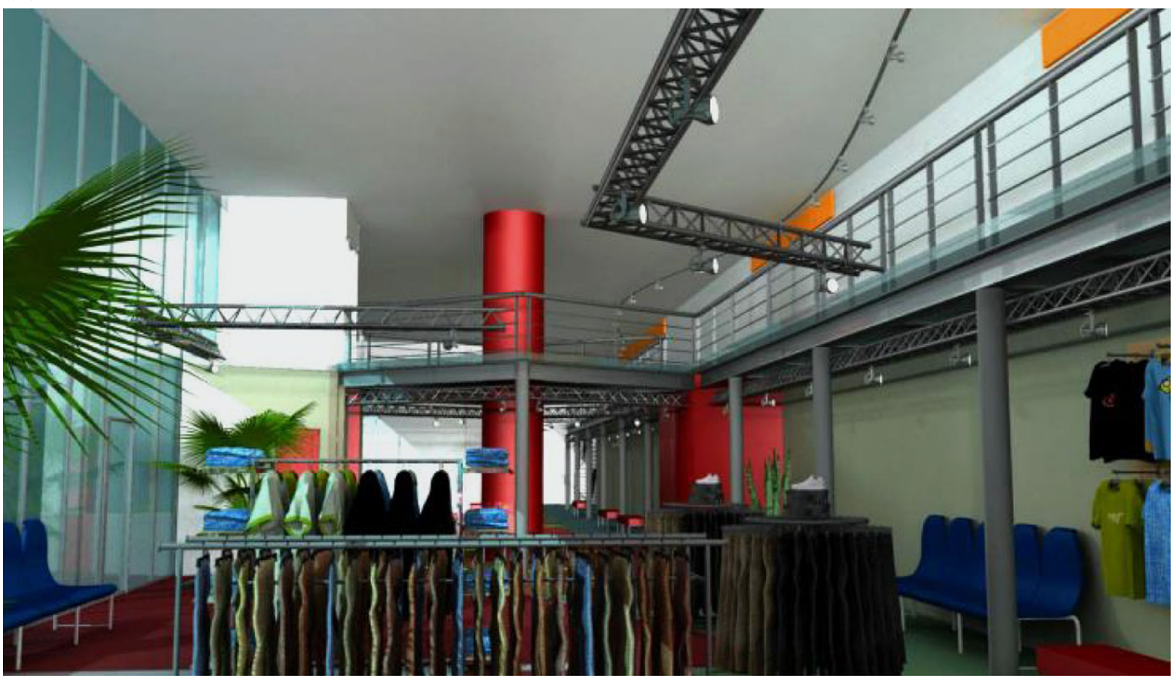

Virtual retail environments

171

Plate 1.

The virtual retail environment where our experiment took place

The simulation was made available at the psychology laboratory of a university in southern Italy, where a convenience sample of engineering undergraduate students and staff were invited to attend the experiment. Participants were asked to attend both experiments, one for the immersive retail store environment, and another with the complete simulation presented on a traditional desktop screen. The same participants, thus, attended both the desktop and the immersive environment experiments. The two experiments were conducted on two separate days. On one day, 150 participants tested the desktop technology, while on another day (which they had previously chosen on the basis that they would do so on a different day between 3 and 30 days from the desktop technology testing) the same 150 people attended the experiment based on the test of immersive technology. Although a 
factorial design may have been more effective, this arrangement was adopted given that we only had a single immersive experimental setup and participants' availability was constrained by inelastic commitments. Similarly, the order and time between the two runs was driven by the pragmatic scope imposed by the availability of the 3D setup.

The sample consisted of 59 females and 91 males. The greater number of males arises from the composition of the engineering department, but also reflects the likely composition of innovator consumers with a new online shopping technology (Dennis et al., 2009). In all, 85 per cent were aged between 21 and 30 and all had at least high school education. In all, 96 per cent were students, appropriate as they are more representative of online shopping customers than are the general population (Alsajjan and Dennis, 2010).

Participants were asked to explore the immersive store by wearing special glasses equipped with polarised lenses (for correct 3D visualisation) and a data glove (for browsing the environment) and fill in a questionnaire about their experience. They were not represented in the virtual world by avatars in order to guarantee a more realistic experience, given that the avatar's personality may not necessarily mirror that of the user (Lin and Wang, 2013). Participants were further invited to undertake the tasks assigned. They were first introduced into a virtual bookstore in order to familiarise themselves with the 3D environment, functions and interaction modality, under the guidance of an experienced researcher. Next, participants autonomously explored a fashion retail store under two different graphic resolution modes (low and high), in order to elicit whether different graphic resolutions might influence consumers' perception of the simulation experience. The high resolution version featured $2,048 \times 768$ dpi horizontal split resolution, while the low one $1,280 \times 720$. Thus, the experiment was set in two different environments providing differing qualities of graphics. Each participant could complete the following tasks in about ten minutes: go to the upper floor (choosing lift or stairs according to personal preference), find a particular T-shirt among those in the available collection and pick one that they would like to buy, choose a pair of jeans, reach the fitting room (without trying them on), approach the relaxing area for a quick rest. Participants were then asked to complete the same questionnaire after the virtual exploration of the environment under the two different graphic resolutions.

Similarly, the desktop-based and immersion-based presentations used identical resolutions and functionalities. The desktop simulation allows consumers to visualise the environment through a traditional display (rather than the large screen used for the immersive system), and to browse the environment through a joystick. In contrast to the immersion-based presentation, the desktop version does not require the user to wear any data glove or special glasses with polarised lenses.

So both environments are 3D, but the modalities of interaction and the quality of graphics and realism change totally. The processes of the experiments are presented in Table I.

\section{Results}

The following results have been generated using the partial least square (PLS) approach. Since the model in this study is a synthesis of earlier work, the literature suggests that PLS is a better approach compared with other SEM tools (Chin et al., 2003; Gefen et al., 2000; Reinartz et al., 2009). In this study, we used SmartPLS Version 2.0 (Ringle et al., 2005) to conduct the analyses including validity measures (Henseler et al., 2008). Tables II and III present the descriptive statistics of indicators, composite reliability, Cronbach's $\alpha$, and standardised factor loadings. All our constructs were measured using a seven-point Likert scale. All standardised factor loadings are significant, most of the factor loadings are higher than 0.6, which is considered high (Hair et al., 1998), and the other three factor loadings are higher than 0.4, which is acceptable (Raubenheimer, 2004), indicating convergent validity. The composite reliabilities, and Cronbach's $\alpha$ of the constructs are all larger than the 0.7 threshold, indicating acceptable reliability (Boudreau et al., 2001). 


\begin{tabular}{|c|c|c|c|c|c|}
\hline & Group 1 & Group 2 & Group 3 & Group 4 & nt \\
\hline Scenarios & Desktop high & Desktop low & Immersive high & Immersive low & \\
\hline Resolution & $2,048 \times 768 \mathrm{dpi}$ & $1,280 \times 720 \mathrm{dpi}$ & $2,048 \times 768 \mathrm{dpi}$ & $1,280 \times 720 \mathrm{dpi}$ & \\
\hline Time duration & \multicolumn{2}{|c|}{ First day } & \multicolumn{2}{|c|}{$\begin{array}{l}\text { A different day between } 3 \text { to } 30 \text { days } \\
\text { after testing desktop technology }\end{array}$} & \\
\hline Total Time for completing all tasks & \multirow{3}{*}{\multicolumn{2}{|c|}{$\begin{array}{l}\text { About } 10 \text { minutes } \\
\text { Browse the environment }\end{array}$}} & \multirow{3}{*}{\multicolumn{2}{|c|}{$\begin{array}{l}\text { About } 10 \text { minutes } \\
\text { A briefing that introduced the } \\
\text { virtual bookstore to enable subjects } \\
\text { to familiarise themselves with the } 3 \mathrm{D} \\
\text { scenario }\end{array}$}} & \\
\hline Task 1 & & & & & \\
\hline & & & & & \\
\hline Task 2 & \multicolumn{4}{|c|}{ Go to the upper floor } & \\
\hline Task 3 & \multicolumn{4}{|c|}{ Find a particular T-shirt } & \\
\hline Task 4 & \multicolumn{4}{|c|}{ Choose a pair of jeans } & \\
\hline Task 5 & \multicolumn{4}{|c|}{ Reach the fitting room } & \\
\hline Task 6 & \multicolumn{4}{|c|}{ Approach the relaxing area } & Table I. \\
\hline Task 7 & \multicolumn{4}{|c|}{ Fill in the questionnaire } & Experiment processes \\
\hline
\end{tabular}

Tables IV and V report the descriptive statistics of constructs and the correlations between them. The average variances extracted (AVEs) and correlations were used to assess discriminant validity. All the AVEs were found to be above 0.5 , indicating that more than half of the variance observed in the items used was accounted for by their hypothesised constructs (Hair et al., 1998). All squared correlations are lower than the corresponding AVEs, implying acceptable discriminant validity. Nevertheless, Kock (2015) demonstrates that even when discriminant validity is satisfactory, common methods bias (CMB) can still be an issue and recommends a full collinearity assessment. Kock and Lynn (2012) recommend an upper variance inflation factor (VIF) threshold of five for SEM models of this type. The highest VIF is 4.20 and we accordingly conclude that $\mathrm{CMB}$ is not an issue in our model.

\section{Empirical results for both immersive and desktop groups}

We adopted the PLS SEM for hypothesis testing. PLS does not generate as many goodnessof fit indices as covariance-based SEM does (Hu and Bentler, 1999). The percentage of variance explained is indicated by the $R^{2}$ as a measure of the overall model fit (Henseler et al., 2008). One-tailed $t$-tests were used to test the significance of each of the path coefficients. The sample consists of two conditions. The first is the "immersive" environment, where 150 people interacted with the 3D setup. The other is the "desktop" environment, in which 150 people used the desktop screen. Figure 2 shows the path coefficients generated from the desktop environment and Figure 3 shows the path coefficients generated from the immersive environment. All path coefficients are presented on the respective arrows, and the figures in the circle are the $R^{2}$. All path coefficients are significant at the 1 per cent level. $H 1-H 6$ are supported. For the desktop environment, the three constructs (simulated experience, hedonic value and utilitarian value) explain 26 per cent of engagement. Engagement further explains 33 per cent of the enjoyment and 50 per cent of satisfaction. Finally, the satisfaction level accounts for 22 per cent of purchase intention. For the immersive environment, the simulated experience, hedonic value and utilitarian value explain half of the variance in engagement. Engagement explains 57 per cent of enjoyment and 27 per cent of satisfaction. More than half of the purchase intention ( 52 per cent) is explained by satisfaction.

\section{Multi-group comparison}

We analysed the resolution difference and immersion environment difference by conducting multi-group comparisons. The data are first divided into four groups: the "immersive" group 
ITP

30,1

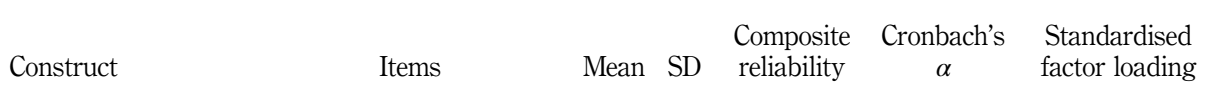

174

3D authenticity
(Algharabat and Dennis, 2010a)

3DAuth1

$\begin{array}{ll}5.87 & 0.88\end{array}$

0.98

0.973

0.97

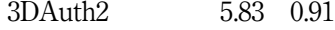

$\begin{array}{ll}5.82 & 0.91\end{array}$

$\begin{array}{lll}\text { 3DAuth3 } & 5.82 & 0.91 \\ \text { 3DAuth4 } & 5.80 & 0.95\end{array}$

Engagement (Ghani, 1995)

EN1

EN2

EN3

EN4

Colour vividness

Colour1

(Fiore, Kim and Lee, 2005b;

Klein, 2003; Steuer, 1992)

Control (Liu and Shrum, 2002;

Colour2

Colour3

Mcmillan and Hwang, 2002;

Con1

Song and Zinkhan, 2008)

Con2

Con3

Con4

Con5

Enjoyment (Ghani, 1995)

Enjoy1

Enjoy2

Enjoy3

Enjoy4

Graphics vividness

(Fiore, Kim and Lee, 2005b;

Graph1

Graph2

Klein, 2003; Steuer, 1992)

Hedonic value

(Babin et al., 1994)

Graph3

Hed1

Hed2

Hed3

Hed4

Purchase intention

PI1

(Fiore, Kim and Lee, 2005b)

PI2

$\begin{array}{ll}5.80 & 0.95 \\ 2.26 & 0.96\end{array}$

$2.01 \quad 0.86$

$\begin{array}{ll}2.01 & 0.85\end{array}$

$2.10 \quad 1.04$

$\begin{array}{ll}6.31 & 0.90\end{array}$

$\begin{array}{ll}6.29 & 0.80\end{array}$

$\begin{array}{ll}6.29 & 0.80\end{array}$

$\begin{array}{ll}5.95 & 1.18\end{array}$

$5.95 \quad 1.18$

$\begin{array}{ll}5.93 & 1.19\end{array}$

$5.95 \quad 1.18$

$\begin{array}{ll}5.96 & 1.19\end{array}$

$2.28 \quad 1.10$

$\begin{array}{ll}2.24 & 1.02\end{array}$

$\begin{array}{ll}2.25 & 0.99\end{array}$

$2.30 \quad 1.06$

$\begin{array}{ll}6.28 & 0.80\end{array}$

$\begin{array}{ll}6.27 & 0.79\end{array}$

$\begin{array}{ll}6.26 & 0.80\end{array}$

$4.89 \quad 1.44$

$\begin{array}{ll}5.47 & 1.20\end{array}$

$5.52 \quad 1.16$

$\begin{array}{ll}5.50 & 1.17\end{array}$

$\begin{array}{ll}5.85 & 0.99\end{array}$

$5.49 \quad 1.14$

$\begin{array}{lll}\text { PI3 } & 5.38 & 1.21\end{array}$

PI4

Satisfaction

Sat1

(Bhattacherjee, 2001)

Sat2

$\begin{array}{ll}5.72 & 1.27\end{array}$

$\begin{array}{ll}5.96 & 0.83\end{array}$

$6.00 \quad 0.65$

$5.95 \quad 0.64$

Sat3

Sat4

Utilitarian value

Uti1

(Fiore, Kim and Lee, 2005b)

Uti2

$\begin{array}{ll}5.95 & 0.72\end{array}$

$\begin{array}{ll}5.66 & 1.00\end{array}$

$\begin{array}{ll}5.67 & 0.99\end{array}$

$\begin{array}{ll}5.67 & 0.99\end{array}$

Uti4

$\begin{array}{ll}5.59 & 1.05\end{array}$

Table II.

Simulated experience

3D authenticity

Graphic

$\begin{array}{ll}5.83 & 0.91\end{array}$

Colour vividness

$\begin{array}{ll}6.27 & 0.80\end{array}$

properties of

indicators for

desktop group

Note: ${ }^{\text {RReverse coded }}$

0.98

0.90

0.94

0.95

$\begin{array}{lll} & & \\ 0.99 & 0.984 & 0.82 \\ & & 0.97\end{array}$

0.99

0.99

$\begin{array}{lll}1.00 & 0.998 & 1.00\end{array}$

1.00

0.99

1.00

1.00

$\begin{array}{lll}0.87 & 0.794 & 0.76\end{array}$

0.80

0.83

0.76

$\begin{array}{lll}1.00 & 0.997 & 0.99\end{array}$

1.00

1.00

$\begin{array}{lll}0.94 & 0.906 & 0.67\end{array}$

0.96

0.97

0.96

$\begin{array}{lll}0.89 & 0.829 & 0.83\end{array}$

0.88

0.88

0.68

$\begin{array}{lll}0.92 & 0.870 & 0.74\end{array}$

0.93

0.94

0.81

$\begin{array}{lll}0.98 & 0.971 & 0.98\end{array}$

0.98

0.99

0.89

$\begin{array}{lll}0.96 & 0.953 & 0.74\end{array}$

0.91

0.92

0.67

with high resolution (immerse high), the "immersive" group with low resolution (immerse low), the "desktop" group with high resolution (desk high) and the "desktop" group with low resolution (desk low). Each of the four groups has 150 data points. The resolution differences are compared between desktop high and desktop low (Tables IV and V), and between immerse high and immerse low (Table VI). Then, the full data set is divided into "immersive" and "desktop" group, with each group containing 300 data points, and the path coefficients are compared between these two larger groups (Table VII). 


\begin{tabular}{|c|c|c|c|c|c|c|c|}
\hline Construct & Items & Mean & $\mathrm{SD}$ & $\begin{array}{l}\text { Composite } \\
\text { reliability }\end{array}$ & $\begin{array}{c}\text { Cronbach's } \\
\alpha\end{array}$ & $\begin{array}{l}\text { Standardised } \\
\text { factor loading }\end{array}$ & environments \\
\hline \multirow{4}{*}{$\begin{array}{l}\text { 3D authenticity (Algharabat } \\
\text { and Dennis, 2010a) }\end{array}$} & 3DAuth1 & 5.38 & 1.51 & \multirow[t]{4}{*}{0.95} & \multirow[t]{4}{*}{0.926} & 0.64 & \\
\hline & 3DAuth2 & 5.63 & 1.17 & & & 0.61 & \\
\hline & 3DAuth3 & 5.40 & 1.47 & & & 0.65 & \\
\hline & 3DAuth4 & 5.38 & 1.51 & & & 0.64 & \\
\hline \multirow[t]{4}{*}{ Engagement (Ghani, 1995) ${ }^{\mathrm{a}}$} & EN1 & 2.82 & 1.34 & \multirow[t]{4}{*}{0.99} & \multirow[t]{4}{*}{0.988} & 0.73 & 175 \\
\hline & EN2 & 2.84 & 1.35 & & & 0.73 & \\
\hline & EN3 & 2.82 & 1.33 & & & 0.74 & \\
\hline & EN4 & 2.85 & 1.35 & & & 0.72 & \\
\hline Colour vividness & Colour1 & 5.46 & 1.42 & 0.99 & 0.990 & 0.70 & \\
\hline (Fiore, Kim and Lee, 2005b; & Colour2 & 5.50 & 1.40 & & & 0.71 & \\
\hline Klein, 2003; Steuer, 1992) & Colour3 & 5.52 & 1.40 & & & 0.71 & \\
\hline Control (Liu and Shrum, 2002; & Con1 & 5.58 & 1.31 & 0.97 & 0.951 & 0.74 & \\
\hline Mcmillan and Hwang, 2002; & Con2 & 5.58 & 1.29 & & & 0.76 & \\
\hline \multirow[t]{3}{*}{ Song and Zinkhan, 2008) } & Con3 & 5.59 & 1.27 & & & 0.77 & \\
\hline & Con4 & 5.61 & 1.26 & & & 0.77 & \\
\hline & Con5 & 5.51 & 1.33 & & & 0.52 & \\
\hline \multirow[t]{4}{*}{ Enjoyment (Ghani, 1995) ${ }^{\mathrm{a}}$} & Enjoy1 & 2.91 & 1.42 & \multirow[t]{4}{*}{0.96} & \multirow[t]{4}{*}{0.944} & 0.58 & \\
\hline & Enjoy2 & 2.79 & 1.54 & & & 0.62 & \\
\hline & Enjoy3 & 2.78 & 1.58 & & & 0.60 & \\
\hline & Enjoy4 & 2.74 & 1.58 & & & 0.62 & \\
\hline Graphics vividness & Graph1 & 5.52 & 1.39 & 1.00 & 0.996 & 0.72 & \\
\hline (Fiore, Kim and Lee, 2005b; & Graph2 & 5.50 & 1.40 & & & 0.72 & \\
\hline Klein, 2003; Steuer, 1992) & Graph3 & 5.50 & 1.41 & & & 0.71 & \\
\hline Hedonic value & Hed1 & 5.16 & 1.54 & \multirow{4}{*}{0.99} & \multirow{4}{*}{0.984} & 0.63 & \\
\hline \multirow[t]{3}{*}{ (Babin et al., 1994) } & Hed2 & 5.23 & 1.53 & & & 0.64 & \\
\hline & Hed3 & 5.22 & 1.52 & & & 0.64 & \\
\hline & Hed4 & 5.29 & 1.50 & & & 0.65 & \\
\hline Purchase Intention & PI1 & 4.39 & 1.45 & \multirow[t]{4}{*}{0.97} & \multirow[t]{4}{*}{0.958} & 0.67 & \\
\hline \multirow[t]{3}{*}{ (Fiore, Kim and Lee, 2005b) } & PI2 & 4.37 & 1.46 & & & 0.67 & \\
\hline & PI3 & 4.39 & 1.48 & & & 0.66 & \\
\hline & PI4 & 4.84 & 1.55 & & & 0.55 & \\
\hline Satisfaction & Sat1 & 4.65 & 1.49 & \multirow[t]{4}{*}{0.99} & \multirow[t]{4}{*}{0.985} & 0.64 & \\
\hline \multirow[t]{3}{*}{ (Bhattacherjee, 2001) } & Sat2 & 4.76 & 1.41 & & & 0.70 & \\
\hline & Sat3 & 4.76 & 1.43 & & & 0.69 & \\
\hline & Sat4 & 4.74 & 1.43 & & & 0.69 & \\
\hline Utilitarian value & Uti1 & 4.63 & 1.55 & \multirow[t]{4}{*}{0.99} & \multirow[t]{4}{*}{0.990} & 0.64 & \\
\hline \multirow[t]{3}{*}{ (Fiore, Kim and Lee, 2005b) } & Uti2 & 4.62 & 1.55 & & & 0.64 & \\
\hline & Uti3 & 4.63 & 1.55 & & & 0.64 & \\
\hline & Uti4 & 4.63 & 1.60 & & & 0.61 & \\
\hline \multirow[t]{4}{*}{ Simulated experience } & 3D Authenticity & 5.45 & 1.43 & 0.96 & 0.959 & 0.80 & \\
\hline & Graphic & 5.51 & 1.40 & & & 0.94 & Table III. \\
\hline & $\begin{array}{l}\text { Colour } \\
\text { Vividness }\end{array}$ & 5.49 & 1.40 & & & 0.93 & Measurement \\
\hline & Control & 5.57 & 1.29 & & & 0.73 & $\begin{array}{l}\text { properttes of } \\
\text { indicators for }\end{array}$ \\
\hline Note: ${ }^{\text {aReverse coded }}$ & & & & & & & immersive group \\
\hline
\end{tabular}

Tables VI-VIII present the evaluation results of the structural model. The bootstrap analysis is used to assess the differences between groups. In each iteration, the number of cases is set equal to the specific sample size (Sarstedt et al., 2011). The bootstrap iteration was set equal to 1,000 (Chin, 1998; Chin and Dibbern, 2010) and 5,000 (Sarstedt et al., 2011) (also tested with the bootstrap iteration equal to 2,000 to assess whether they are in agreement).

As reported in Tables VII-VIII, the comparisons between desk low and desk high, and between immerse low and immerse high, do not show any significant difference 
Mean SD 3D Col. Con. Eng. Enj. Gra. Hed. PI Sat. Sim. Uti.

\section{6}

3D authenticity
Colour
Control
Engagement
Enjoyment
Graphic
Hedonic value
Purchase intention
Satisfaction
Simulated experience
Utilitarian value

$5.83 \quad 1.43(0.93)$

$\begin{array}{llll}6.30 & 1.40 & 0.22 & (0.97)\end{array}$

$\begin{array}{lllll}5.95 & 1.29 & 0.09 & 0.33 & (0.99)\end{array}$

$\begin{array}{llllll}2.10 & 1.34 & 0.16 & 0.09 & 0.04 & (0.75)\end{array}$

$\begin{array}{lllllll}2.27 & 1.53 & 0.41 & 0.14 & 0.05 & 0.33 & (0.62)\end{array}$

$\begin{array}{llllllll}6.27 & 1.40 & 0.20 & 0.94 & 0.29 & 0.12 & 0.14 & (0.99)\end{array}$

$\begin{array}{lllllllll}5.35 & 1.52 & 0.09 & 0.07 & 0.01 & 0.15 & 0.37 & 0.08 & (0.81)\end{array}$

$\begin{array}{llllllllll}5.61 & 1.50 & 0.11 & 0.04 & 0.01 & 0.17 & 0.19 & 0.06 & 0.17 & (0.68)\end{array}$

Table IV

Measurement properties of constructs for desktop group

Note: Values on diagonal are AVEs, whilst those below the diagonal are squared correlations 


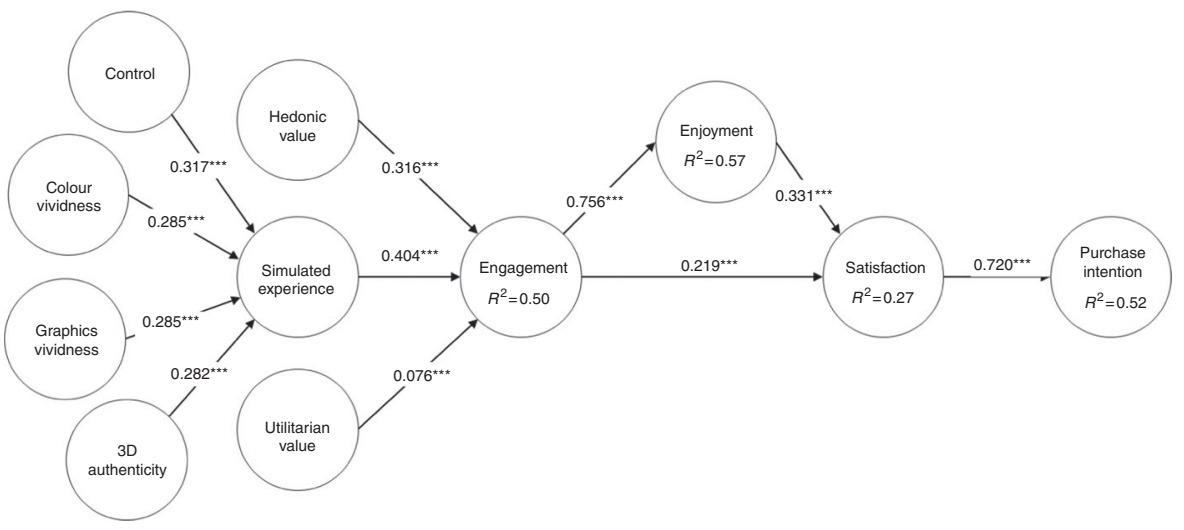

Notes: ns, not significant. ***,***Significant at $10,5,1$ per cent level, respectively

\begin{tabular}{lrrrrrr}
\hline & \multicolumn{2}{c}{$\begin{array}{c}\text { Desk low } \\
\end{array}$} & \multicolumn{2}{c}{ Desk high } & & \multicolumn{3}{c}{$p$-value (iteration $=$ ) } \\
& Path & Path & Group difference & 1,000 & 2,000 & 5,000 \\
\hline 3D authenticity $\rightarrow$ simulated experience & 0.271 & 0.275 & 0.004 & 0.946 & 0.944 & 0.943 \\
Engagement $\rightarrow$ enjoyment & 0.581 & 0.595 & 0.015 & 0.861 & 0.859 & 0.856 \\
Engagement $\rightarrow$ satisfaction & -0.420 & -0.462 & -0.042 & 0.752 & 0.744 & 0.749 \\
Colour vividness $\rightarrow$ simulated experience & 0.278 & 0.274 & -0.005 & 0.849 & 0.847 & 0.850 \\
Control $\rightarrow$ simulated experience & 0.399 & 0.396 & -0.003 & 0.953 & 0.953 & 0.953 \\
Enjoyment $\rightarrow$ satisfaction & -0.364 & -0.338 & 0.026 & 0.828 & 0.825 & 0.825 \\
Graphic vividness $\rightarrow$ simulated experience & 0.285 & 0.281 & -0.004 & 0.863 & 0.861 & 0.863 \\
Hedonic value $\rightarrow$ engagement & -0.221 & -0.294 & -0.073 & 0.546 & 0.550 & 0.552 \\
Satisfaction $\rightarrow$ purchase intention & 0.477 & 0.486 & 0.009 & 0.895 & 0.895 & 0.894 \\
Simulated experience $\rightarrow$ engagement & -0.228 & -0.226 & 0.001 & 0.938 & 0.937 & 0.937 \\
Utilitarian value $\rightarrow$ engagement & -0.214 & -0.186 & 0.028 & 0.817 & 0.813 & 0.814
\end{tabular}

\section{Virtual retail environments}

177

Figure 3.

Empirical results from immersive data

\begin{tabular}{|c|c|c|c|c|c|c|c|}
\hline & $\begin{array}{c}\text { Immerse } \\
\text { low } \\
\text { Path }\end{array}$ & $\begin{array}{c}\text { Immerse } \\
\text { high } \\
\text { Path }\end{array}$ & $\begin{array}{c}\text { Group } \\
\text { difference }\end{array}$ & $\begin{array}{r}p \\
\text { (iter } \\
1,000\end{array}$ & $\begin{array}{c}p \text {-value } \\
\text { eration } \\
2,000\end{array}$ & $\begin{array}{l}\text { e } \\
=) \\
5,000\end{array}$ & \\
\hline 3D authenticity $\rightarrow$ simulated experience & 0.272 & 0.288 & 0.015 & 0.546 & 0.580 & 0.593 & \\
\hline Engagement $\rightarrow$ enjoyment & 0.745 & 0.774 & 0.029 & 0.727 & 0.720 & 0.711 & \\
\hline Engagement $\rightarrow$ satisfaction & -0.241 & -0.201 & 0.040 & 0.762 & 0.804 & 0.815 & \\
\hline Colour vividness $\rightarrow$ simulated experience & 0.283 & 0.290 & 0.006 & 0.766 & 0.748 & 0.756 & \\
\hline Control $\rightarrow$ simulated experience & 0.319 & 0.312 & -0.006 & 0.881 & 0.815 & 0.819 & \\
\hline Enjoyment $\rightarrow$ satisfaction & -0.276 & -0.382 & -0.107 & 0.484 & 0.542 & 0.544 & Table VII. \\
\hline Graphic vividness $\rightarrow$ simulated experience & 0.281 & 0.294 & 0.014 & 0.574 & 0.532 & 0.531 & Group comparison \\
\hline Hedonic value $\rightarrow$ engagement & -0.268 & -0.362 & -0.094 & 0.482 & 0.497 & 0.489 & between immerse high \\
\hline Satisfaction $\rightarrow$ purchase intention & 0.719 & 0.722 & 0.003 & 0.979 & 0.991 & 0.990 & resolution and \\
\hline Simulated experience $\rightarrow$ engagement & -0.473 & -0.338 & 0.134 & 0.262 & 0.289 & 0.283 & immerse low \\
\hline Utilitarian value $\rightarrow$ engagement & -0.063 & -0.088 & -0.025 & 0.762 & 0.781 & 0.763 & resolution \\
\hline
\end{tabular}

significantly higher loading on simulated experience for the desktop environment (0.399) than for the immersive environment (0.315) at the 1 per cent significance level. In contrast, simulated experience has a higher impact on engagement for the immersive environment (0.402) than the desktop environment (0.222) (but only at the 10 per cent level). 


\begin{tabular}{|c|c|c|c|c|c|c|}
\hline & \multirow{2}{*}{$\begin{array}{c}\text { Immersive } \\
\text { Path }\end{array}$} & \multirow{2}{*}{$\begin{array}{l}\text { Desktop } \\
\text { Path }\end{array}$} & \multirow{2}{*}{$\begin{array}{l}\text { Group } \\
\text { difference }\end{array}$} & \multicolumn{3}{|c|}{$p$-value (iteration $=$ ) } \\
\hline & & & & 1,000 & 2,000 & 5,000 \\
\hline 3D authenticity $\rightarrow$ simulated experience & 0.282 & 0.275 & -0.007 & 0.794 & 0.789 & 0.792 \\
\hline Engag & 0.756 & 0.577 & -0.179 & $0.028 * *$ & $0.027 * *$ & $0.027 * *$ \\
\hline Engagement $\rightarrow$ satisfaction & -0.219 & -0.430 & -0.211 & 0.125 & 0.126 & 0.130 \\
\hline Colour vividness $\rightarrow$ simulated experience & 0.285 & 0.276 & -0.009 & 0.702 & 0.701 & 0.701 \\
\hline Control $\rightarrow$ simulated experience & 0.317 & 0.399 & 0.082 & $0.003 * * *$ & $0.003^{* * * *}$ & $0.003 * * *$ \\
\hline Enjoyment $\rightarrow$ satisfaction & -0.331 & -0.357 & -0.026 & 0.853 & 0.853 & 0.854 \\
\hline \multicolumn{7}{|l|}{ Graphic vividness $\rightarrow$ simulated } \\
\hline $\begin{array}{l}\text { experience } \\
\text { Hedonic value } \rightarrow \text { engagement }\end{array}$ & 0.285 & 0.283 & -0.001 & 0.949 & 0.950 & $\begin{array}{l}0.949 \\
0.546\end{array}$ \\
\hline Hedonic value $\rightarrow$ engagement & -0.316 & -0.245 & 0.072 & 0.539 & 0.547 & 0.546 \\
\hline Satisfaction $\rightarrow$ purchase intention & 0.720 & 0.471 & -0.249 & $0.000 * * *$ & $0.001 * * *$ & $0.001^{* * * *}$ \\
\hline Simulated experience $\rightarrow$ engagement & -0.404 & -0.222 & 0.182 & $0.068 *$ & $0.067 *$ & $0.069 *$ \\
\hline Utilitarian value $\rightarrow$ engagement & -0.076 & -0.198 & -0.122 & 0.187 & 0.183 & 0.182 \\
\hline Notes: $* p<0.1 ; * * p<0.05 ; * * * p<0$. & & & & & & \\
\hline
\end{tabular}

Table VIII.

Group comparison between the immersive group and the desktop group
The immersive environment also has a higher loading on the path between "engagement" and "enjoyment" at the 5 per cent significance level. Finally, satisfaction has a larger effect on purchase intention in the immersive environment (0.716) than the desktop environment (0.474) at the 1 per cent significance level. The average value of constructs in each comparative group for different scenarios is shown in Table IX.

\section{Discussion}

Our work has filled a key gap in the literature by testing a theoretical, integrative model and developing a theoretical path which maps consumer behaviour leading to purchase intention. A cross-analysis of this integrative model/theoretical path within two virtual retail environments provided numerous theoretical and managerial insights for immersive environments, making a major contribution to this field of study.

Specifically, the findings support the conceptual model, extending Papagiannidis et al.'s (2013) work to the context of an immersive 3D retail store environment enabled by virtual reality technology, where participants wear special glasses and a data glove. Our model predicts that telepresence (control, colour vividness, graphic vividness and $3 \mathrm{D}$ authenticity) has positive effects on simulated experience ( $H 1 a-d$, respectively), which in turn positively affects engagement (H1e). The results support past work (Fiore, Kim and Lee, 2005; Fiore and Kim, 2007; Song and Zinkhan, 2008) indicating that control plays a role in building user engagement. The findings also confirm prior studies by Shih (1998), Fiore, Jin and Kim (2005), Fiore, Kim and Lee (2005) and Steuer (1992) that colourful, vivid graphics create higher levels

\begin{tabular}{lcccccc} 
Construct & Desktop high & Desktop low & Immersive high & Immersive low & Desktop & Immersive \\
\hline Control(5) & 5.945 & 5.945 & 5.616 & 5.533 & 5.945 & 5.575 \\
Colour vividness(3) & 6.309 & 6.282 & 5.662 & 5.322 & 6.296 & 5.492 \\
Graph vividness (3) & 6.282 & 6.256 & 5.684 & 5.329 & 6.269 & 5.507 \\
3D authenticity(4) & 5.858 & 5.805 & 5.568 & 5.327 & 5.832 & 5.448 \\
Enjoyment(4) & 2.258 & 2.277 & 2.672 & 2.935 & 2.268 & 2.803 \\
Engagement(3) & 2.789 & 2.802 & 3.718 & 3.838 & 2.796 & 3.778 \\
Satisfaction(4) & 6.008 & 5.922 & 4.775 & 4.683 & 5.965 & 4.729 \\
Hedonic value(4) & 5.368 & 5.322 & 5.278 & 5.168 & 5.345 & 5.223 \\
Utilitarian value(4) & 5.673 & 5.622 & 4.662 & 4.593 & 5.648 & 4.628 \\
Purchase intention(4) & 5.767 & 5.453 & 4.628 & 4.363 & 5.610 & 4.496 \\
\hline
\end{tabular}

Table IX.

Average score of constructs for different scenarios 
of user engagement. The results are in line with studies by Algharabat and Dennis (2010b) supporting the role of 3D authenticity in user engagement. Through engagement, the telepresence components, along with utilitarian value $(H 1 f)$ and hedonic value $(H 1 g)$, indirectly positively influence the enjoyment a user derives from experiencing the simulated retail environment (H2). This finding confirms previous studies, for example, by Ghani (1995), as well as past work in relation to flow theory (Turkay and Adinolf, 2010; D'alba et al., 2011; Mollen and Wilson, 2010; Oulasvirta et al., 2005; Ghani and Deshpande, 1994). Similarly, both enjoyment $(H 3)$ and engagement $(H 4)$ positively influence user satisfaction with the simulated retail environment, a finding that corresponds with previous work by Van Vugt et al. (2006; 2009) and Sylaiou et al. (2010) on virtual environments. In turn, satisfaction from experiencing the simulated retail environment influences the intention to purchase the clothing item involved (H5). This finding is consistent with many past marketing studies that have examined the link between satisfaction and purchase intention for various contexts (e.g. Hausman and Siekpe, 2009; Fiore, Jin and Kim, 2005; Fiore, Kim and Lee, 2005 in online environments). Overall, the findings confirm the role of simulation in encouraging users to engage more with products and services in virtual environments and to improve their experience (e.g. Algharabat and Dennis, 2010b). Resolution, when sufficiently high, has little impact on this psychological process, confirming previous findings by Papagiannidis et al. (2013). The results can be interpreted as meaning that, provided a minimum standard is reached, authenticity is less dependent on the quality of the graphics or other ICT factors but more perhaps on the degree to which the users can relate to the experience, as operationalised in this study by the degree of immersion.

Offering multiple ways that are customisable in order to communicate product and service information can help not only engage customers more, but even create additional revenues streams (Lowe et al., 2013). Consequently, understanding the impact change to an interface can have becomes very important. The results of the comparison between the immersive and desktop environments indicate significant differences on several paths. Higher control has less impact on simulated experience for the immersive environment than for the desktop. This difference may be because when an immersive environment is available, people pay much more attention to the visual aspects and the authenticity (i.e. colour vividness, graphic vividness and 3D authenticity), while control becomes less important. Similarly, simulated experience has significantly higher impact on engagement in the immersive environment. Notably, in the immersive environment, half of the variance of engagement is explained by simulated experience, hedonic value, utilitarian value; the impact of simulated experience is significantly higher than for the desktop environment $(H 6 a)$. This is unsurprising, since the simulated experience in front of an immersive screen better resembles reality, reducing the negative impact of using an artificial system. There is also a difference between the two environments in terms of the effects of attentional involvement on enjoyment: engagement in the immersive environment explains perceived enjoyment better $(H 6 b)$. This may be because the participants in the immersive environment experience something novel and the enjoyment mainly comes from the involvement that they had seldom experienced previously. In comparison, participants in the desktop environment sought enjoyment from other dimensions since they were more familiar with virtual stores on computer screens. Contrary to the expectation, the influence of enjoyment on satisfaction is greater for participants in the desktop environment than for participants in the immersive environment, although the difference is not significant ( $\mathrm{H} 6 \mathrm{c}$ not supported). Participants may have been expecting an enjoyable experience from the immersive environment; and therefore, may have adjusted expected standards of satisfaction upwards accordingly. They may still perceive the 3D environment as being at the developmental stage and further technical and operational improvements are required. Finally, the purchase intention of participants in the immersive environment is
Virtual retail environments 
more related to the satisfaction from the virtual store $(H 6 d)$. The reason may be that participants can connect the experience in the virtual store to the experience in a real store more easily in the immersive environment.

\section{Conclusions, managerial implications and future research}

This work has evaluated a robust model of purchase intention and demonstrated it to hold (for clothing purchases) not only in a 3D environment on a conventional computer platform but also in an immersive one, where participants wear special glasses and a data glove. Purchase intention is influenced by satisfaction, which is in turn influenced by enjoyment and engagement. Engagement in turn is influenced by utilitarian and hedonic value and the experience of product simulation or telepresence, which is composed of control, 3D authenticity, colour and graphics vividness.

Traditional in-store shopping can stimulate pleasure, enjoyment and excitement (Hart et al., 2014) whilst online shopping has been said to offer little experience value (Mathwick et al., 2001). However, more recent research suggests that shoppers also seek out recreational, enjoyable aspects of online shopping (Fiore, Jin and Kim, 2005; Konus et al., 2008). This study draws attention to the important differences between the two online environments, in that in the immersive environment, experience is more associated with engagement and enjoyment, leading to a greater purchase intention. The immersive, 3D environment, thus, has the potential to rival traditional shopping in terms of experience, resulting in higher sales for the retailers and satisfaction for the consumers. More importantly, these new environments (including the immersive one) differ radically from other, traditional shopping channels. Based on work by Alba et al. (1997), Childers et al. (2001, p. 515) argue that this is due to "the absence of the actual experience of visiting the store and physically examining a product prior to purchase". It is evident, then, that we are experiencing fundamental and revolutionary changes in relation to shopping channels and consumer behaviour.

Overall, this work has generated many implications for marketing theory. The first relates to the retail theatre concept (see Healy et al., 2007), which our study extends to the virtual world by active and continuous engagement via 3D and an immersive environment, where participants wear special glasses and a data glove, which creates an unforgettable retail experience. The retail experience could be further developed by, for example, facilitating the shopper's co-creation value (Kohler et al., 2011), e.g. by customising the product in terms of colour and size or even the retail space itself. Further, users could get involved with testing new clothing products and concepts within the virtual store and could provide their experience and views back to the retailer. For example, users could provide their views about a new virtual store layout and whether its design corresponds well with the merchandising (and products) on sale. The importance of experience has been noted in the past in both the marketing (experiential marketing, see Schmitt, 1999) and retailing (experiential retailing, see Kim, 2001) domains but limited work has been done in relation to virtual worlds from the retail marketing perspective. In our experiment we have only examined one aspect of the user experience, relating to the interaction between the user and the virtual retail environment. Retail theatre and co-creation of value would be even more effective if users interacted with either other human actors, such as shop assistants and other customers, or computer-generated ones, such as avatars. Retailers need to be strategic when assigning virtual identities to consumers or assistants as they can influence consumer behaviour in different ways (Yoo et al., 2015).

Building on the principle of the immersive environment, live interactions with store employees and other customers could provide a more lively and realistic retail experience that could be compared with electronic versions of the same roles, for example, using 
avatars. In addition, future research could potentially compare conventional web-based applications vs virtual world-based applications for the same retailer and product types, examining the relative importance of purchase decision-making factors. Future studies could examine whether virtual retailing is significantly affected by differences in consumers' cultures and whether there are any differences between demographic groupings (e.g. age, income, socioeconomic status, etc.). The latter research will be very useful considering that our research focussed on a specific consumer segment, the student market. Future research could also examine consumer behaviour in these $3 \mathrm{D}$ environments as consumers operate nowadays as "inexperienced" shoppers here due to the new, original and innovative retail atmosphere presented to them (Jin, 2009). This also calls for a future longitudinal study which will revisit this work and test whether new results are generated and whether the immersive environment has become more "accepted" and, therefore, participants feel more "experienced" with it. The above indicates possible future research areas where we could test our conceptual framework further. It also presents an excellent opportunity to shed further light on the application of the retail theatre concept in relation to non-traditional environments such as virtual ones.

This work has generated numerous managerial implications. First, it has become clear that immersive environments present an innovative tool facilitating a new retail store model based on relevant technologies. These environments can provide excellent platforms for retail managers to test various marketing strategies including new product development, promotions, store atmospherics, etc. In this vein, immersive environments can become a major link in a multichannel strategy where various shopping channels will operate in an integrated fashion. Immersive environments are a market niche nowadays but they have a promising future and companies need to incorporate the above within their strategies. Managers could make use of models like the one proposed when employing these immersive environments with the ultimate aim of influencing consumers' future product purchases. However, managers need to be aware that the consumers may nowadays have high expectations from these immersive environments and, therefore, they will need to adjust and factor this in when setting up relevant strategies.

To conclude, this paper has highlighted the role of immersive environments for retailers' current and future marketing strategies and we hope that attention will be paid to our recommendations.

\section{References}

Alba, J., Lynch, J., Weitz, B., Janiszewski, C., Lutz, R. and Sawyer, A. et al. (1997), "Interactive home shopping: consumer, retailer and manufacturer incentives to participate in electronic marketplaces", Journal of Marketing, Vol. 61 No. 3, pp. 38-53.

Algharabat, R. and Dennis, C. (2010a), "3D product authenticity model for online retail: an invariance analysis", International Journal of Business Science \& Applied Management, Vol. 5 No. 3, pp. 14-30.

Algharabat, R. and Dennis, C. (2010b), "Using authentic 3D product visualisation for an electrical online retailer", Journal of Customer Behaviour, Vol. 9 No. 2, pp. 97-115.

Algharabat, R. and Dennis, C. (2011), "Modelling the impact of 3D authenticity and 3D telepresence on behavioural intention for an online retailer", in Dirk, M., Thomas, R., Peter, S., Hanna, S.K. and Bernhard, S. (Eds), European Retail Research, Gabler Verlag, Wiesbaden, pp. 93-109, doi: 10.1007/978-3-8349-6147-1_4.

Al-Qeisi, K., Dennis, C., Jayawardhena, C. and Alamanos, E. (2014), "Website design quality and usage behaviour: an application of the UTAUT model", Journal of Business Research, Vol. 67 No. 11, pp. 2282-2290.

Alsajjan, B. and Dennis, C. (2010), "Internet banking acceptance model: a cross-market examination", Journal of Business Research, Vol. 63, pp. 957-963.
Virtual retail environments

181 
Animesh, A., Pinsonneault, A., Sung-Byung, Y. and Wonseok, O. (2011), "An odyssey into virtual worlds: exploring the impacts of technological and spatial environments on intention to purchase virtual products”, MIS Quarterly, Vol. 35 No. 3, pp. 789-810.

Babin, B.J., Darden, W.R. and Griffin, M. (1994), "Work and/or fun: measuring hedonic and utilitarian shopping value”, Journal of Consumer Research, Vol. 20 No. 4, pp. 644-656.

Bakker, A.B., Albrecht, S.L. and Leiter, M.P. (2011), "Work engagement: further reflections on the state of play", European Journal of Work and Organizational Psychology, Vol. 20 No. 1, pp. 74-88.

Barnes, S.J., Mattsson, J. and Hartley, N. (2015), "Assessing the value of real-life brands in virtual worlds”, Technological Forecasting and Social Change, Vol. 92, March, pp. 12-24.

Bartle, R. (2004), Designing Virtual Worlds, New Riders, Berkeley, CA.

Bhattacherjee, A. (2001), "Understanding information systems continuance: an expectationconfirmation model", MIS Quarterly, Vol. 25 No. 3, pp. 351-370.

Blazquez, M. (2014), "Fashion shopping in multichannel retail: the role of technology in enhancing the customer experience", International Journal of Electronic Commerce, Vol. 18 No. 4, pp. 97-116.

Boudreau, M.C., Gefen, D. and Straub, D.W. (2001), "Validation in information systems research: a state-of-the-art assessment”, MIS Quarterly, Vol. 25 No. 1, pp. 1-15.

Bourlakis, M., Papagiannidis, S. and Li, F. (2009), "Retail spatial evolution: paving the way from traditional to metaverse retailing”, Electronic Commerce Research, Vol. 9 No. 1, pp. 135-148.

Cheng, L.K., Chieng, M.-H. and Chieng, W.H. (2014), "Measuring virtual experience in a three-dimensional virtual reality interactive simulator environment: a structural equation modelling approach”, Virtual Reality, Vol. 18 No. 3, pp. 173-188.

Childers, T.L., Carr, C.L., Peck, J. and Carson, S. (2001), "Hedonic and utilitarian motivations for online retail shopping behavior", Journal of Retailing, Vol. 77 No. 4, pp. 511-535.

Chin, W.W. (1998), “The partial least squares approach to structural equation modeling”, in Hoyle, R.H. (Ed.), Modern Methods for Business Research, Lawrence Erlbaum, Mahwah, NJ, pp. 295-336.

Chin, W.W. and Dibbern, J. (2010), "An introduction to a permutation based procedure for multi-group PLS analysis: results of tests of differences on simulated data and a cross cultural analysis of the sourcing of information system services between Germany and the USA", in Vinzi, V.E., Chin, W.W., Henseler, J. and Wang, H. (Eds), Handbook of Partial Least Squares, Springer, Berlin and Heidelberg.

Chin, W.W., Marcolin, B.L. and Newsted, P.R. (2003), "A partial least squares latent variable modeling approach for measuring interaction effects: results from a Monte Carlo simulation study and an electronic-mail emotion/adoption study”, Information Systems Research, Vol. 14 No. 2, pp. 189-217.

Choi, Y.K. and Taylor, C.R. (2014), "How do 3-dimensional images promote products on the internet?", Journal of Business Research, Vol. 67 No. 10, pp. 2164-2170.

Coursaris, C., Swierenga, S.J. and Watrall, E. (2008), "An empirical investigation of color temperature and gender effects on web aesthetics", Journal of Usability Studies, Vol. 3 No. 3, pp. 103-117.

Cronin, J.J., Brady, M.K. and Hult, G.T.M. (2000), "Assessing the effects of quality, value and customer satisfaction on consumer behavioural intentions in service environments", Journal of Retailing, Vol. 76 No. 2, pp. 193-218.

Csikszentmihalyi, M. (1990), Flow: The Psychology of Optimal Experience, Harper \& Row, New York, NY.

D'alba, A., Najmi, A., Gratch, J. and Bigenho, C. (2011), "Virtual learning environments. the oLTECx: a study of participant attitudes and experiences", International Journal of Gaming and Computer-Mediated Simulations, Vol. 3 No. 1, pp. 33-50.

Demirkan, H. and Spohrer, J. (2014), "Developing a framework to improve virtual shopping in digital malls with intelligent self-service systems", Journal of Retailing and Consumer Services, Vol. 21 No. 5 , pp. 860-868.

Dennis, C. and Jayawardhena, C. (2010), "Antecedents of internet shopping intentions and the moderating effects of substitutability", International Review of Retail, Distribution and Consumer Research, Vol. 20 Nos 9-10, pp. 411-430. 
Dennis, C., Jayawardhena, C., Merrilees, W. and Wright, L.T. (2009), “e-Consumer behaviour”, European Journal of Marketing, Vol. 43 Nos 9/10, pp. 1121-1139.

Dennis, C., Morgan, A., Wright, L.T. and Jayawardhena, C. (2010), "The influence of social e-shopping in enhancing young women's online shopping behaviour", Journal of Customer Behaviour, Vol. 9 No. 2, pp. 151-174.

Domina, T., Lee, S.E. and Macgillivray, M. (2012), "Understanding factors affecting consumer intention to shop in a virtual world", Journal of Retailing and Consumer Services, Vol. 19 No. 6, pp. 613-620.

Donovan, R.J., Rossiter, J.R., Marcoolyn, G. and Nesdale, A. (1994), "Store atmosphere and purchasing behaviour”, Journal of Retailing, Vol. 70 No. 3, pp. 283-294.

Eroglu, S.A., Macleit, K.A. and Davis, L.M. (2003), "Empirical testing of a model of online store atmospherics and shopper responses”, Psychology and Marketing, Vol. 20 No. 2, pp. 139-150.

Fiore, A.M. and Kim, J. (2007), "An integrative framework capturing experiential and utilitarian shopping experience", International Journal of Retail and Distribution Management, Vol. 35 No. 6, pp. 421-442.

Fiore, A.M., Jin, H.J. and Kim, J. (2005), "For fun and profit: hedonic value from image interactivity and responses toward an online store", Psychology \& Marketing, Vol. 22 No. 8, pp. 669-694.

Fiore, A.M., Kim, J. and Lee, H.H. (2005), "Effect of image interactivity technology on consumer responses toward the online retailer", Journal of Interactive Marketing, Vol. 19 No. 3, pp. 38-53.

Gadalla, E., Keeling, K. and Abosag, I. (2013), "Metaverse-retail service quality: a future framework for retail service quality in the 3D internet", Journal of Marketing Management, Vol. 29 Nos 13-14, pp. 1493-1517.

Gefen, D., Straub, D. and Boudreau, M.-C. (2000), "Structural equation modeling and regression: guidelines for research practice", Communications of the Association for Information Systems, Vol. 4, Article 7.

Ghani, J.A. (1995), "Flow in human computer interactions: test of a model", in Carey, J. (Ed.), Human Factors in Information Systems: Emerging Theoretical Bases, Ablex Publishing Corporation, NJ.

Ghani, J.A. and Deshpande, S.P. (1994), "Task characteristics and the experience of optimal flow in human-computer interaction”, Journal of Psychology, Vol. 128 No. 4, pp. 381-391.

Guo, Y. and Barnes, S. (2011), "Purchase behavior in virtual worlds: an empirical investigation in second life", Information \& Management, Vol. 48 No. 2, pp. 303-312.

Guttentag, D.A. (2010), "Virtual reality: applications and implications for tourism", Tourism Management, Vol. 31 No. 5, pp. 637-651.

Hair, J.F., Anderson, R.E., Tatham, R.L. and Black, W.C. (1998), Multivariate Data Analysis, Prentice-Hall, Upper Saddle River, NJ.

Handelsman, M.M., Briggs, W.L., Sullivan, N. and Towler, A. (2005), "A measure of college student course engagement”, Journal of Educational Research, Vol. 98 No. 3, pp. 184-191.

Hart, C., Stachow, G., Rafiq, M. and Laing, A. (2014), “Customer experience of town centres”, ESRC report, Loughborough University, Loughborough.

Hassouneh, D. and Brengman, M. (2011), "Shopping in virtual worlds: perceptions, motivations, and behavior", Journal of Electronic Commerce Research, Vol. 12 No. 4, pp. 320-335.

Hausman, A.V. and Siekpe, J.S. (2009), "The effect of web interface features on consumer online purchase intentions", Journal of Business Research, Vol. 62 No. 1, pp. 5-13.

Healy, M.J., Beverland, M.B., Oppewal, H. and Sands, S. (2007), "Understanding retail experiences - the case for ethnography”, International Journal of Market Research, Vol. 49 No. 6, pp. 751-778.

Henseler, J., Ringle, C.M. and Sinkovics, R.R. (2008), "The use of partial least squares path modeling in international marketing", in Sinkovics, R.R. and Ghauri, P.N. (Eds), New Challenges to International Marketing, Emerald Group Publishing Limited, pp. 277-319. 
Hernandez, B., Jimenez, J. and Martin, M.J. (2009), "The impact of self-efficacy, ease of use and usefulness on e-purchasing: an analysis of experienced e-shoppers", Interacting with Computers, Vol. 21 Nos 1-2, pp. 146-156.

Hopping, D. (2000), “Technology in retail”, Technology in Society, Vol. 22 No. 1, pp. 63-74.

Houliez, C. (2010), "Branding places or branding spatial practices? Retail spaces in the age of mixed realities", Place Branding and Public Diplomacy, Vol. 6 No. 2, pp. 87-96.

Hu, L. and Bentler, P.M. (1999), "Cutoff criteria for fit indexes in covariance structure analysis: conventional criteria versus new alternatives", Structural Equation Modeling, Vol. 6 No. 1, pp. $1-55$.

Hu, P.J.H. and Hui, W. (2012), "Examining the role of learning engagement in technology-mediated learning and its effects on learning effectiveness and satisfaction”, Decision Support Systems, Vol. 53 No. 4, pp. 782-792.

Jiang, Z. and Benbasat, I. (2004), "Virtual product experience: effects of visual and functional control of products on perceived diagnosticity and flow in electronic shopping", Journal of Management Information Systems, Vol. 21 No. 3, pp. 111-147.

Jin, S.A.A. (2009), "The roles of modality richness and involvement in shopping behaviour in 3D virtual stores", Journal of Interactive Marketing, Vol. 23, pp. 234-246.

Jones, M.A. (1999), "Entertaining shopping experiences: an exploratory investigation", Journal of Retailing and Consumer Services, Vol. 6 No. 3, pp. 129-139.

Jones, M.A., Reynolds, K.E. and Arnold, M.J. (2006), "Hedonic and utilitarian shopping value: investigating differential effects on retail outcomes", Journal of Business Research, Vol. 59 No. 9 , pp. 974-981.

Kaplan, A.M. (2012), "If you love something, let it go mobile: mobile marketing and mobile social media $4 \times 4$ ", Business Horizons, Vol. 55 No. 2, pp. 129-139.

Kim, J. and Forsythe, S. (2007), "Hedonic usage of product virtualisation technologies in online apparel shopping", International Journal of Retail \& Distribution Management, Vol. 35 No. 6, pp. 502-514.

Kim, K.K., Shin, H.K. and Kim, B. (2011), "The role of psychological traits and social factors in using new mobile communication services", Electronic Commerce Research and Applications, Vol. 10 No. 4, pp. 408-417.

Kim, Y.H., Kim, D.J. and Wachter, K. (2013), “A study of mobile user engagement (MoEN): engagement motivations, perceived value, satisfaction, and continued engagement intention”, Decision Support Systems, Vol. 56, December, pp. 361-370.

Kim, Y.K. (2001), "Experiential retailing: an interdisciplinary approach to success in domestic and international retailing", Journal of Retailing and Consumer Services, Vol. 8 No. 5, pp. 287-289.

Klein, L.R. (2003), "Creating virtual product experiences: the role of telepresence", Journal of Interactive Marketing, Vol. 17 No. 1, pp. 41-55.

Kock, N. (2015), "Common method bias in PLS-SEM: a full collinearity assessment approach", International Journal of e-Collaboration, Vol. 11 No. 4, pp. 1-10.

Kock, N. and Lynn, G.S. (2012), "Lateral collinearity and misleading results in variance-based SEM: an illustration and recommendations", Journal of the Association for Information Systems, Vol. 13 No. 7, pp. 546-580.

Kohler, T., Fueller, J., Matzler, K. and Stieger, D. (2011), "Co-creation in virtual worlds: the design of the user experience”, MIS Quarterly, Vol. 35 No. 3, pp. 773-788.

Konus, U., Verhoef, P.C. and Neslin, S.A. (2008), "Multichannel shopper segments and their covariates", Journal of Retailing, Vol. 84 No. 4, pp. 398-413.

Koufaris, M. (2002), "Applying the technology acceptance model and flow theory to online consumer behaviour”, Information Systems Research, Vol. 13 No. 2, pp. 205-223.

Krasonikolakis, I., Vrechopoulos, A. and Pouloudi, A. (2014), "Store selection criteria and sales prediction in virtual worlds", Information \& Management, Vol. 51 No. 6, pp. 641-652. 
Kushwaha, T. and Shankar, V. (2013), "Are multichannel customers really more valuable? The moderating role of product category characteristics”, Journal of Marketing, Vol. 77 No. 4, pp. 67-85.

Laria, G. and Pantano, E. (2012), "Introduction of innovative retail systems based on immersive environments", International Journal of Digital Content Technology and its Application, Vol. 6 No. 2, pp. 248-254.

Lee, K.Y. (2012), "Consumer processing of virtual experience in e-commerce: a test of an integrated framework", Computers in Human Behavior, Vol. 28, November, pp. 2134-2142.

Lee, S.E. and Domina, T. (2013), "Shopping in a virtual world: an analysis of young users' experiences", The International Journal of Technology, Knowledge, and Society, Vol. 8 No. 4, pp. 13-24.

Lehdonvirta, V., Wilska, T.-A. and Johnson, M. (2009), "Virtual consumerism", Information, Communication \& Society, Vol. 12 No. 7, pp. 1059-1079.

Lin, H. and Wang, H. (2013), "Avatar creation in virtual worlds: behaviors and motivations", Computers in Human Behavior, Vol. 34 No. 34, pp. 213-218.

Liu, Y. and Shrum, L.J. (2002), "What is interactivity and is it always such a good thing? Implications of definition, person and situation for the influence of interactivity on advertising effectiveness", Journal of Advertising, Vol. 31 No. 4, pp. 53-64.

Lowe, B., De Souza-Monteiro, D. and Fraser, I. (2013), "Nutritional labelling information: utilisation of new technologies", Journal of Marketing Management, Vol. 29 Nos 11-12, pp. 1337-1366.

Mcmillan, S.J. and Hwang, J.S. (2002), "Measures of perceived interactivity: an exploration of the role of direction of communication, user control, and time in shaping perceptions of interactivity", Journal of Advertising, Vol. 31 No. 3, pp. 29-42.

Malliet, S. (2006), “An exploration of adolescents' perception of videogame realism”, Learning, Media and Technology, Vol. 31 No. 4, pp. 377-394.

Mäntymäki, M. and Salo, J. (2011), "Teenagers in social virtual worlds: continuous use and purchasing behavior in Habbo Hotel", Computers in Human Behavior, Vol. 27 No. 6, pp. 2088-2097.

Martineau, P. (1958), "The personality of the retail store", Harvard Business Review, Vol. 36, January/Feburary, pp. 47-55.

Mathwick, C., Malhotra, N. and Rigdon, E. (2001), "Experiential value: conceptualization, measurement and application in the catalog and internet shopping environment", Journal of Retailing, Vol. 77 No. 1, pp. 39-56.

Mehrabian, A. and Russell, J.A. (1974), An Approach to Environmental Psychology, MIT Press, Cambridge, MA.

Messinger, P.R., Stroulia, E., Lyons, K., Bone, M., Niu, R.H., Smirnov, K. and Perelgut, S. (2009), "Virtual worlds - past, present, and future: new directions in social computing", Decision Support Systems, Vol. 47 No. 3, pp. 204-228.

Minsky, M. (1980), “Tele-presence”, Omni, pp. 45-51, available at: http://web.media.mit.edu/ minsky/ papers/Telepresence.html (accessed 15 January 2015).

Mollen, A. and Wilson, H. (2010), "Engagement, telepresence and interactivity in online consumer experience; reconciling scholastic and managerial perspectives", Journal of Business Research, Vol. 63 Nos 9-10, pp. 919-925.

Nah, F.F.-H., Eschenbrenner, B. and Dewester, D. (2011), "Enhancing brand equity through flow and telepresence: a comparison of 2D and 3D virtual worlds", MIS Quarterly, Vol. 35 No. 3, pp. 731-347.

Olsen, S.O. and Skallerud, K. (2011), "Retail attributes' differential effects on utilitarian versus hedonic shopping value", Journal of Consumer Marketing, Vol. 28 No. 7, pp. 532-539.

Oulasvirta, A., Tamminen, S., Roto, V. and Kuorelahti, J. (2005), "Interaction in 4-second bursts: the fragmented nature of attentional resources in mobile HCI", SIGCHI Conference on Human Factors in Computing Systems, Portland, OR. 
Pantano, E. (2014), "Innovation drivers in retail industry", Journal of Information Management, Vol. 34 No. 3, pp. 344-350.

Pantano, E. and Naccarato, G. (2010), "Entertainment in retailing: the role of advanced technologies", Journal of Retailing and Consumer Services, Vol. 17 No. 3, pp. 200-204.

Pantano, E. and Servidio, R. (2012), "Modeling innovative points of sales through virtual and immersive technologies", Journal of Retailing and Consumer Services, Vol. 19 No. 3, pp. 279-286.

Pantano, E. and Viassone, M. (2015), "Engaging consumers on new integrated multichannel retail settings: challenges for retailers", Journal of Retailing and Consumer Services, Vol. 25, July, pp. 106-114.

Papagiannidis, S. and Bourlakis, M. (2010), "Staging the new retail drama: at a metaverse near you!", Journal of Virtual Worlds Research, Vol. 5 No. 2, pp. 3-17.

Papagiannidis, S., Bourlakis, M.A. and Li, F. (2008), "Making real money in virtual worlds: MMORPGs and emerging business opportunities, challenges and ethical implications in metaverses", Technological Forecasting and Social Change, Vol. 75 No. 5, pp. 610-622.

Papagiannidis, S., Pantano, E., See-To, E. and Bourlakis, M. (2013), "Modelling the determinants of a simulated experience in a virtual retail store and users' product purchasing intentions", Journal of Marketing Management, Vol. 29 Nos 13-14, pp. 1462-1492.

Parke, F.I. (2005), "Lower cost spatially immersive visualization for human environments", Landscape and Urban Planning, Vol. 73 Nos 2-3, pp. 234-243.

Poncin, I. and Mimoun, M.S.B. (2014), "The impact of 'e-atmospherics' on physical stores”, Journal of Retailing and Consumer Services, Vol. 21 No. 5, pp. 851-859.

Prahalad, C.K. and Ramaswamy, V. (2004), "Co-creation experiences: the next practice in value creation”, Journal of Interactive Marketing, Vol. 18 No. 3, pp. 5-14.

Raubenheimer, J.E. (2004), "An item selection procedure to maximize scale reliability and validity", South African Journal of Industrial Psychology, Vol. 30 No. 4, pp. 59-64.

Reinartz, W., Haenlein, M. and Henseler, J. (2009), "An empirical comparison of the efficacy of covariance-based and variance-based SEM", International Journal of Research in Marketing, Vol. 26 No. 4, pp. 332-344.

Ringle, C.M., Wende, S. and Will, A. (2005), "SmartPLS 2.0 (beta)", available at: www.smartpls.de (accessed 1 February 2015).

Sarstedt, M., Henseler, J. and Ringle, C.M. (2011), "Multigroup analysis in partial least squares (PLS) path modeling: alternative methods and empirical results", in Sarstedt, M., Schwaiger, M. and Taylor, C.R. (Eds), Measurement and Research Methods in International Marketing, (Advances in International Marketing), Vol. 22, Emerald Group Publishing Limited, pp. 195-218.

Schmitt, B. (1999), "Experiential marketing", Journal of Marketing Management, Vol. 15 Nos 1-3, pp. 53-67.

Sheridan, T.B. (1992), "Musings on telepresence and virtual presence", Presence, Vol. 1 No. 1, pp. 120-126.

Shih, C. (1998), "Conceptualising consumer experiences in cyberspace", European Journal of Marketing, Vol. 32 Nos 7-8, pp. 655-663.

Song, J.H. and Zinkhan, G.M. (2008), "Determinants of perceived web site interactivity", Journal of Marketing Research, Vol. 72 No. 2, pp. 99-113.

Steuer, J. (1992), "Defining virtual reality: dimensions determining telepresence", Journal of Communication, Vol. 42 No. 4, pp. 73-93.

Sukoco, B.M. and Wu, W.Y. (2011), "The effects of advergames on consumer telepresence and attitudes: a comparison of products with search and experience", Expert Systems with Applications, Vol. 38 No. 6, pp. 7396-7406.

Sylaiou, S., Mania, K., Karoulis, A. and White, M. (2010), "Exploring the relationship between presence and enjoyment in a virtual museum", International Journal of Human-Computer Studies, Vol. 68 No. 5, pp. 243-253. 
Turkay, S. and Adinolf, S. (2010), "Free to be me: a survey study on customization with World of Warcraft and City of Heroes/Villains players", Procedia Social and Behavioral Sciences, Vol. 2 No. 2, pp. 1840-1845.

Van Vugt, H.C., Hoorn, J.F. and Konijn, E.A. (2009), "Interactive engagement with embodies agents: an empirically validated framework", Computer Animation and Virtual Worlds, Vol. 20 Nos 2-3, pp. 195-204.

Van Vugt, H.C., Konijn, E.A., Hoorn, J.F., Keur, I. and Eliens, A. (2006), "Realism is not all! user engagement with task-related interface characters", Interacting with Computers, Vol. 19 No. 2, pp. 267-280.

Verhagen, T., Swen, E., Feldberg, F. and Merikivi, J. (2015), " Benefitting from virtual customer environments: an empirical study of customer engagement”, Computers in Human Behavior, Vol. 48, July, pp. 340-357.

Verhagen, T., Feldberg, F., Hooff, B.V.D., Meents, S. and Merikivi, J. (2011), "Satisfaction with virtual worlds: an integrated model of experiential value", Information and Management, Vol. 48 No. 6, pp. 201-207.

Verhagen, T., Feldberg, F., Van Den Hooff, B., Meents, S. and Merikivi, J. (2012), “Understanding users' motivations to engage in virtual worlds: a multipurpose model and empirical testing", Computers in Human Behavior, Vol. 28 No. 2, pp. 484-495.

Verhoef, P.C., Lemon, K.N., Parasuraman, A., Roggeveen, A., Tsiros, M. and Schlesinger, L.A. (2009), "Customer experience creation: determinants, dynamics and management studies", Journal of Retailing, Vol. 85 No. 1, pp. 31-41.

Vila, N. and Kuster, I. (2011), "Consumer feelings and behaviours towards well designed websites", Information Management, Vol. 48 Nos 4/5, pp. 166-177.

Vorderer, P. (1992), Watching Television as Action: Reception of TV Movies from the Perspective of Motivational Psychology, Edition Sigma, Berlin.

Weibel, D. and Wissmath, B. (2011), "Immersion in computer games: the role of spatial presence and flow", International Journal of Computer Games Technology, Vol. 2011, Article ID 282345, pp. 1-14.

Yang, H.E. and Wu, C.C. (2009), "Effects of image interactivity technology adoption on e-shoppers' behavioural intentions with risk as moderator", Production Planning \& Control, Vol. 20 No. 4, pp. 370-382.

Yoo, S.-C., Peña, J.F. and Drumwright, M.E. (2015), "Virtual shopping and unconscious persuasion: the priming effects of avatar age and consumers' age discrimination on purchasing and prosocial behaviors", Computers in Human Behavior, Vol. 48, July, pp. 62-71.

Yoo, W.S., Lee, Y. and Park, J. (2010), "The role of interactivity in e-tailing: creating value and increasing satisfaction", Journal of Retailing and Consumer Services, Vol. 17 No. 2, pp. 89-96.

Zhou, Z., Jin, X.-L. and Fang, Y. (2014), "Moderating role of gender in the relationships between perceived benefits and satisfaction in social virtual world continuance", Decision Support Systems, Vol. 65, September, pp. 69-79.

Zhou, Z., Fang, Y., Vogel, D.R., Jin, X.-L. and Zhang, X. (2012), "Attracted to or locked in? Predicting continuance intention in social virtual world services", Journal of Management Information Systems, Vol. 29 No. 1, pp. 273-306.

Zhou, Z., Jin, X.-L., Vogel, D.R., Fang, Y. and Chen, X. (2011), "Individual motivations and demographic differences in social virtual world uses: an exploratory investigation in second life", International Journal of Information Management, Vol. 31 No. 3, pp. 261-271.

\section{About the authors}

Savvas Papagiannidis is the David Goldman Professor of Innovation and Enterprise in the Newcastle University Business School, UK. His work has been published in several academic journals and presented at the international conferences. His research interests mainly revolve around electronic business and its various sub-domains. More specifically, his research aims to inform our understanding of how e-business 
technologies affect the social and business environment, organisational strategies and business models, and how these are implemented in terms of functional innovations. His work puts strong emphasis on innovation, new value creation and the exploitation of entrepreneurial opportunities, within the context of different industries. Savvas Papagiannidis is the corresponding author and can be contacted at: savvas. papagiannidis@ncl.ac.uk

Eleonora Pantano is a Lecturer in Marketing at the Middlesex University of London, UK. Prior to joining Middlesex in February 2015, she was post doc a Research Fellow at the University of Calabria, Italy and a Researcher at the Technical University of Eindhoven, The Netherlands. She holds a $\mathrm{PhD}$ in "Psychology of Programming and Artificial Intelligence" and a Master's Degree in Business Engineering. Her research activities explore marketing management and mainly relate to consumers attitude and acceptance towards new technology-based retail settings, and how business and retail models are implemented in terms of innovation and technology management. Her findings appear in numerous international journals such as Journal of Marketing Management, International Journal of Information Management, and Journal of Retailing and Consumer Services (she was also a Guest Editor of two special issues for this journal and got the Certificate of Excellence in Reviewing for 2013).

Eric W.K. See-To is an Assistant Professor at the Department of Industrial and Systems Engineering, Hong Kong Polytechnic University, and currently an Associate Editor of Electronic Commerce Research. Prior to the current appointment, Eric served as a Senior Lecturer in the Business School, University of Newcastle upon Tyne, UK and as a Lecturer in the Department of Management Science, Lancaster University Management School, UK. His current projects include application of text mining techniques to financial valuation of innovation and intangible assets, and analysis of online opinions and sentiments with social network and data mining. Eric's research focusses on practical applications of business intelligence and knowledge mining. His work has been published in international and top-tier journals such as Journal of Management Information Systems (JMIS), Research Policy, Technological Forecasting and Social Change, Electronic Commerce Research, Electronic Markets, Information Systems Frontiers, and Journal of Electronic Commerce Research.

Charles Dennis is a Professor of Marketing and Retailing at The Business School, Middlesex University, UK and an Associate Editor (Retailing) of the European Journal of Marketing. His main teaching and research area is (e-)retail and consumer behaviour - the vital final link of the marketing process. Charles is a Chartered Marketer, elected as a Fellow of the Chartered Institute of Marketing for helping to modernise the teaching of the discipline. Charles was awarded the Vice Chancellor's Award for Teaching Excellence for improving the interactive student learning experience at the Brunel University. Charles has published in journals such as Journal of Business Research and European Journal of Marketing. Books include Marketing the e-Business, (1st and 2nd editions) (joint-authored with Dr Lisa Harris); the research monograph (combined textbook) e-Retailing (Routledge) and China Logistics Publishing House; and research monograph Objects of Desire: Consumer Behaviour in Shopping Centre Choice (Palgrave). His research into shopping styles has received extensive coverage in the popular media including TV appearances with Sir Trevor McDonald OBE and Adrian Edmondson.

Professor Michael Bourlakis is a Logistics and Supply Chain Management Expert at the Cranfield School of Management, Cranfield University, UK, where he is also the Director of the Demand Chain Management Community and the Head of the Supply Chain Research Centre. Michael has a particular interest in food and retail supply chains and the role of sustainability, e-business and consumer behaviour in relation to supply chains. He has published extensively in these areas generating more than 200 publications including 50 journal papers. He is also a Member of the European Technology Platform (Food for Life, European Commission) and he has secured more than 20 research grants funded by various leading bodies (e.g. EPSRC, TSB, EU FVI, EUFVII, Horizon2020).

For instructions on how to order reprints of this article, please visit our website: 